\title{
Accounting for the fictitious: a Marxist contribution to understanding accounting's roles in the financial crisis
}

\begin{abstract}
This paper presents a contribution to the debates surrounding the culpability of accounting in the recent financial crisis. It adopts a Marxist theoretical perspective concentrating mainly on Marx's work on fictitious capital. Fictitious capital is any form of investment (for example bonds, stocks, derivatives, and collateralized debt obligations) which is based upon the expectation of future returns. According to Marx while fictitious capital is useful to capitalism, it cannot create value only human labour can do that. The recent crisis was exacerbated by the significant amounts of investment which were made in extreme forms of fictitious capital. The paper argues that the accounting profession's adoption of financial economic rationalities meant that it helped to animate the form of financialised neo-liberalism which dominated at the time of the crisis. The accounting profession and accounting academia have implemented and propagated technologies and rationalities which enabled, legitimised, and drove the activities of business in general and financial institutions in particular in the run up to and since the crisis. While, accounting could be seen as being complicit in the crisis, it is important to remember that it was a capitalist crisis. The intuitional structures of accounting mean that it is susceptible of being captured by the most powerful in society.
\end{abstract}

\section{Acknowledgements}

A whole army of people have contributed to this paper which I developed and refined after gracious knowledgeable comments at conferences and I am extremely grateful for them all. In particular I would like to thank Yassamine Mather, Bridget Fowler, Hillel Ticktin and other members of Glasgow University's Centre for the Study of Socialist Theory and Movements, Nihel Chabrak, David Cooper, Yves Gendron, John Roberts, Prem Sikka, Paul Williams and the anonymous reviewers. As ever thanks to Jules too. 
The ideas of economists and political philosophers, both when they are right and when they are wrong, are more powerful than is commonly understood. Indeed the world is ruled by little else. Practical men, who believe themselves to be quite exempt from any intellectual influences, are usually slaves to some defunct economist. Madmen in authority, who hear voices in the air are distilling their frenzy from some academic scribbler a few years back.

Keynes $(1936$, p 383)

.....it has long been evident to dispassionate observers that individual capitalists operating in their own self-interest are prone to behave in such a way as to collectively drive capitalism deeper into crisis. The same can be said of the various factional interests that periodically dominate political and economic power: the bonus-hungry bankers and financiers who now set so much of the agenda in Washington and London ... Individuals and factions pursuing their own particular interests have almost always signally failed to produce a cogent political agenda to stabilise, let alone revive, an ailing capitalist system.

Harvey $(2011$, p 275/6)

In the wake of arguably the worst economic crisis in 80 years, a new debate is gradually opening up about the culpability of accounting in the crisis (Hopwood, 2009). In particular, significant concerns have been raised about the roles of fair value accounting, auditing, off-balance-sheet financing and accounting regulation (Arnold, 2009; Gup and Lutton, 2009; Hatherly, 2013; Krumwiede, 2008; Laux and Leuz, 2009; Magnan and Markarian, 2011; Sikka, 2009; Whittle, et al, forthcoming). At a very basic level one might ask how it could be that large financial institutions with recently audited financial statements showing positive net assets and no audit qualifications could fail so dramatically or require such massive government bail-outs. Following the bail-outs and failures the press was quick to make allusions to Marx but as Kunkel (2011) states; this is a "shallow revival" of Marxist theory perhaps best exemplified by a piece in the UK conservative Spectator Magazine by the Archbishop of Canterbury ${ }^{1}$, Rowan Williams (2008), in which he argued that placing too much trust in the market had become a kind of "idolatry." Williams reminded readers of Karl Marx's criticism of laissez-faire capitalism, noting, "He was right about that, if about little else." This Marxist revival has picked up upon some interesting facets of Marx's work, notably its crisis tendencies but Keynesianism appears to set the left-boundary of economic debate in the press (Kunkel, 2011).

This essay argues that a deeper reading of the work of Marx, especially his work on credit and fictitious capital, can enable a stronger understanding of the crisis and could play a central role in the conceptual discussions about accounting and its role in the crisis. This paper draws upon David Harvey's writings $(2006,2010,2011)$ and Marx's work on the labour theory of value and the credit system including fictitious capital (Marx, nd; 1967; 1973). The use of Marxist theorisation is not new in accounting. For example, Marxist theory has been used to develop a social history of accounting change (eg Armstrong, 1985, 1987; Bryer, 2000a, 2000b, 2005, 2006a; Toms, 2005). Other accounting research has used Marxist theory to develop an understanding of contemporary issues in accounting. For example, in the Special Issue on human rights, in Critical Perspectives on Accounting, several papers draw upon Marxist theory (see for example, Cooper et al, 2011; Sikka 2011). Marxist theory has been used to comprehend accounting's functions in terms of control over the labour process (Arnold, 1998; Cooper and Taylor, 2000; Saravanamuthu and Tinker, 2003; Spence, and Carter, 2011) and deal with contemporary issues like accounting's functions in privatisation (see for example, Arnold and Cooper, 1999; Toms et al, 2011). In terms of the argumentation in this paper, a body of work has been developed which argues that Marx's labour theory of value is superior to marginalist economic theory as the foundation for describing and explaining the role and practices of financial reporting in capitalism (Bryer, 1994, 1999a, Martin,

\footnotetext{
${ }^{1}$ The Archbishop of Canterbury is the senior bishop in the Church of England.
} 
1998). This paper builds upon this body of work by using Marxist theory as a counterweight to financial economic theory which, as will be argued in more detail in the paper, provided the ideological and theoretical underpinning of the structures and activities which enabled impelled and legitimated the events which led to the financial crisis. Financial economics ideas (positive accounting theory, efficient markets hypothesis, agency theory and so on) dominate the field of academic accounting as well as the field of accounting practice.

The crisis demonstrated that financial economic theory serves the interests of some more than others, for while a few individuals were enriched before and by the crisis, it has had a profoundly destructive impact on the majority ${ }^{2}$. Although financial economic theory has been empirically falsified $^{3}$ and continues to wreak havoc and destruction it is very difficult to overcome. For this reason several theorists have described financial economics as zombie economics (see for example, Fine, 2008; Martin, 2002; Quiggin, 2012). This is not simply a question of theoretical niceties; in practice, in 2014, financial institutions and government policies (whose activities are underpinned by financial economics' rationalities) continue to impoverish the lives of the majority of people.

Two aspects of Marxist theory are particularly pertinent for the arguments in this essay -- the labour theory of value and fictitious capital. In Marxism only human labour (work) can create value ${ }^{4}$. Fictitious capital is any form of investment (for example bonds, stocks, derivatives, and collateralized debt obligations) which is based upon the expectation of future returns. Since the expected returns might be produced in the future, they do not currently exist, and, so are fictitious. Marx explains that fictitious capital (especially stocks and credit) serves several important functions under capitalism, not least in terms of enabling capitalist expansion. But, if investment flows to forms of fictitious capital which are not based upon the creation of value, this will, sooner or later, provoke an economic crisis. The flow of money into forms of fictitious capital which are purely speculative and not part of the value creation process (although incredibly profitable for some) exacerbated the recent crisis (see Chabrak, 2014).

The paper is structured as follows. After a deeper consideration of fictitious capital, the paper outlines the form of economic theory, described in the paper as financial economics, which has underpinned neo-liberalism and prioritised the expansion of the markets for fictitious capitals. Next, the paper turns to the impact of financial economics on both professional and academic accountants. Although academic accounting and finance departments provided an incubator for the development of financial economics, the ideology of financial economics is founded upon a belief in unfettered markets and so is against accounting regulation and so presented a challenge to the profession. This is followed by a brief explanation of the growth of financialisation and the scale of the growth and size of the derivatives market. Alongside the growth of derivatives, financialisation penetrated into the everyday lives of individuals and created an economic slowdown. The paper then turns to an explanation of the recent crisis which is described as a mixture of overaccumulation and over-financialisation, or, in other words, too much money searching for profitable investment opportunities and finding the highest returns in speculative fictitious capital aligned to falling wages and the destruction of real capital. Finally, the paper turns to accounting standard setters, the accounting profession and the context within which they operate. It is argued that accounting standard setters and accountants are blinkered by their adoption of and dogged adherence to financial economics as their conceptual frame. Accounting standard setters are

\footnotetext{
${ }^{2}$ See for example, http://wearethe99percent.tumblr.com which sets out personal narratives of ordinary Americans who have played by the rules, worked and studied hard, bought homes for their families, and now feel abandoned and betrayed by the system in which they supported.

${ }^{3}$ This appears to be the case for the majority of activities which are informed by financial economic thought. Quiggin (2012) argues that the US and UK governments are making policy decisions on the basis that the fiscal multiplier is substantial and negative so cutting expenditure will increase output. This claim has no theoretical basis and flawed empirical support.

"This is not to argue that technology is unimportant. Technology is also created by human labour and can be described as "dead labour". Even the most sophisticated machinery has to be operated by humans.
} 
increasingly international and privately funded. Although their rules are sanctioned by nation states, in practice, it would be exceptionally difficult for these states to reject their accounting standards. Finally the paper turns to a discussion of the implications of Marxist theory for accounting, alongside accounting developments since the crisis.

\section{Marx and fictitious capital}

Two facets of Marx's oeuvre underpin fictitious capital ${ }^{5}$. These are the labour theory of value and the understanding of money as a store of the value created by human labour. According to Marx, the new value created by human labour during the working day is split into two - the part paid to labour (their wage earned during the part of the working day described by Marx as necessary labour time) and the part appropriated by their employer (which is produced during the part of the working day which Marx described as surplus labour time). The important element of Marxist theory for those unfamiliar to it is that new value can only be produced by labour. Fictitious capital is based on an expectation about the creation of surplus value (by the workforce) in the future. So for example, if an investor acquires a bond in Company $A$, the price of the bond is based upon an expectation of payments (interest and repayment) which will be met out of future surplus value. Therefore, there is always a speculative element to fictitious capital since, at best, it is based upon the (uncertain) production of surplus value in the future.

There is a qualitative and a quantitative aspect to investment in fictitious capital. Marx wrote that interest is "illusionary" because it appears to come from money-capital itself without any relation to production at all (Marx, 1973). It is "normal" that investors buy bonds and are rewarded (in most cases) with interest. As capitalism developed, people came to believe that money should "grow" over time. Marx described this as a form of fetishism. So, believing that money grows over time, investors will invest in the financial institutions and products which promise the greatest returns. But, if money that is "created" through the finance industry is unsupported by surplus value creation, the currency may be debased, chronic inflation could occur, monetary crises could be created and so on. A financial system which is purely speculative (and not based upon surplus value creation) will undermine the utility of money as a measure and store of value. Yet, investors are, in the main, indifferent to, or ignorant of, the ultimate source of the returns on their investments. This means that money can flow to investments in fictitious capital which is not underpinned by the creation of surplus value thereby creating a financial crisis. Aside from being "illusionary", interest has a quantitative element. It must be paid. Moseley (2011) explains that interest is an element of the distribution of surplus-value which depends upon an agreement between, for example, the banker and the industrial capitalist ${ }^{6}$. So, interest payments reduce the amount of profit which can be kept by the owners of a business. This means that, for example, in the case of a banker loaning money to an industrial capitalist, one can only gain at the expense of the other. ${ }^{7}$

Although fictitious capital presents certain vulnerabilities (in terms of its potential to create financial instability), Marx wrote that the credit system and its outgrowth, fictitious capital, are essential to the expansion of capitalism and can even out many of the frictions of capitalism (Harvey, 2006, p 239, p 284; see also Kunkel, 2011). Thus for example, Harvey (2006) explains that shares are forms of fictitious capital that played an essential role in the early growth of capitalism, which in order to rapidly expand, had to be liberated from the constraints of the family firm - shareholder owned companies enabled substantial investments in technology, the reaping of economies of scale and so on. The money received from initial share issues could have been used to acquire "real capital" -

\footnotetext{
${ }^{5}$ The term did not originate with Marx. Adam Smith had previously used the concept in the Wealth of Nations.

${ }^{6}$ In Vol III of Capital, Marx places interest alongside other individual parts of surplus value for example rent.

${ }^{7}$ As will be argued later in the paper, this natural antagonism between finance and industrial capital is an important factor in the development of financialisation.

8 "Real capital" is money which is invested in the means of production.
} 
"The stocks of railways, mines, navigation companies, and the like, represent actual capital, namely, the capital invested and functioning in such enterprises, or the amount of money advanced by the stockholders for the purpose of being used as capital in such enterprises. .... But this capital does not exist twice, once as the capital-value of titles of ownership (stocks) on the one hand and on the other hand as the actual capital invested, or to be invested, in those enterprises. It exists only in the latter form, and a share of stock is merely a title of ownership to a corresponding portion of the surplus-value to be realised by it. A may sell this title to $B$, and $B$ may sell it to $C$. These transactions do not alter anything in the nature of the problem. A or B then has his title in the form of capital, but $C$ has transformed his capital into a mere title of ownership to the anticipated surplus-value from the stock capital." (Marx, nd, pp 319 - 320)."

Therefore when $\mathrm{C}$ acquires shares, they are bought with the expectation of future returns (based upon future surplus value), or as finance theory would suggest, based on predictions of the future cash flows and profitability of the business. The acquisition of shares by $C$ provides no new investment in the company. Shares can be bought and sold many times over as if they were wealth itself, although in fact, their market prices represent expected future returns.

Harvey (2006) argues that the credit system and fictitious capital were unique to the capitalist mode of production. However, although fictitious capital is essential to capitalism (for its expansion and overcoming timing differences) (Harvey, 2010) it cannot create value: 'There is no substitute for the actual transformation of nature through the concrete production of use values' Kunkel (2011). Importantly, there are some forms of fictitious capital that are more removed from the value creation process than others. As explained later, some forms of fictitious capital are little more than "investment-gambles", which if don't come off, are like any losing book-maker gambling-slips, worthless pieces of paper. The recent financial crisis came about in part because of a massive expansion in gambling (trading) in these slips of paper. This raises the question as to what institutional structures and ideologies facilitated gambling (trading) and what are the drivers behind it.

Thus far, an explanation of Marx's understanding of fictitious capital has been presented in order to provide an alternative perspective on the current economic crisis. In short, money cannot grow in value on its own. Investment takes place within social, economic and political institutional structures. The legitimating structures which enable an understanding of what is allowable and what is not allowable in society are significant (Berger and Luckmann, 1966; Hines, 1988a).

Berger and Luckmann's four levels of legitimation present a robust and coherent framework for understanding the function of linguistic and social structures. Their first level of legitimation is linguistic. Our language (broadly construed) allows us to name and hence to "know" certain things and by having a word for something we must grant its claim to exist. The second level is "theoretical propositions in rudimentary form". This level includes myths, stories and other forms of anecdotal evidence which are used to justify certain social events or relations. The third level consists of explicit theories linked to particular organisational contexts. This would include financial economic theory. Finally, the highest level of legitimation is what Berger and Luckmann describe as "symbolic universes". These are able to tie together different institutional environments to explain their interrelation ${ }^{9}$. It is possible to describe the current "symbolic universe" as neo-liberal.

\footnotetext{
${ }^{9}$ So for example, the English language has the word "market". This gives tangibility to what in certain situations could be fairly intangible. At the second level there are myths surrounding the "market". So, for example, it is deemed to have a superior governance function (see Chabrak, 2014) and an "invisible hand". At the third level, these myths have been given legitimacy through mainstream economic theories
} 
While there is not an explicit or coherent theory of neo-liberalism, it is a widely used and accepted term with common referents (Clegg et al, 2011). Importantly for the arguments in this paper, a particular economic theory has come to form part of the knowledge-base for contemporary economic, political and social practices (level 3 legitimation). Several economists and writers have called this theoretical economic form zombieeconomics, while others (for example, Power, 2010) call it financial economics and others mainstream economics; yet as will be set out in the next section, the term zombieeconomics has some explanatory power. For ease of exposition, in this essay, the dominant form of economic theory under neo-liberalism will be called financial economics.

\section{Zombieconomics, neo-liberalism and social legitimation.}

Fine (2008) sets out a clear summary of the most important facets of neoliberalism and its zombielike qualities as follows-

There are two reasons why the mainstream economics in the current phase of neoliberalism is zombie-like. First, it is both dead and alive at the same time, undead as popular culture would have it. That it prevails within its own disciplinary boundaries with little or no contest and with scant respect for alternatives is more or less uncontroversial. No one can doubt that there are zombieconomists out there and that they are extraordinarily powerful and almost impossible to slay. They are totally insensitive to the considerations of the living but merely respond to an inner inescapable logic and, occasionally, perpetrate mysterious jerking movements of their own. (Fine, 2008, p1)

Tracing the evolution of contemporary economics from the marginalist revolution of the 1870s through the Keynesian revolution and the monetarist counterrevolution to the current phase of (financial) economics in which much economic analysis and analysis from other disciplines (which have been "touched" by financial economics to become like it) Fine (2008) notes that economics has become largely reduced to the optimising behaviour of individuals in face of market imperfections. He goes on to argue that it is the reduction of a very complex world to "individuals and markets" that endows zombieconomics with so much life but with so little content both in terms of analytical elements and as a tool for understanding the broader social aspects of contemporary capitalism. Fine (2008) argues that zombieconomics is dead in that it is based upon an unquestioned methodological individualism and a narrow technical apparatus. It appears to be totally ignorant of its own history and methodology. It fails to engage with alternatives except to dismiss them as unscientific and lacking in rigour (Fine, 2008); even though its own intellectual fragilities are striking (Fine, 2007b). As shall be described later, in the realm of academia, mainstream accounting and finance share the same failure to engage, dismiss alternatives as unscientific and suffer from serious theoretical fragilities. In the realm of policy, due to its very narrow focus, financial economics seeks interventions to correct market imperfections on a piecemeal basis. In the realm of practice, it has been argued that, UK Hedge Funds and Private Equity firms are like zombies which extract value from companies, and also destroy them (Shaxson, 2013).

While Fine (2008) charts the evolution of contemporary economics from the nineteenth century, he and other contemporary theorists (Foucault, 2000) have credited Hayek's (1943), "Road to Serfdom," as one of the major theoretical works, which sets out the economic rationalities (financial economics) for neo-liberalism. Hayek's ideas did not become dominant at the time in which he was writing, they re-emerged with the collapse of the post-war boom in the 1970s, the crisis of

which are used in institutions. Finally, "market theories" are used in several institutional settings. So market prices are used by the state as "true values", by accounting standard setters as the best source of information and so on. 
Keynesianism, and the resurgence of monetarism. MacKenzie (2006) explains how "financial markets" grew in prestige with the "failure" of Keynesianism. Fine (2008) notes that, unburdened by any memory of the extraordinary qualifications that had been necessary to allow them in the first place Hayek's marginalist/individualist principles remained sacrosanct to those in the Chicago school who built upon Hayek's oeuvre. The Chicago School reduced the idea of expectations to the domain of knowable outcomes with attached probabilities (Friedman, 1953). And the theory of rational expectations portrayed individuals as able to "optimise" by modelling the economy. Fine (2008, p 12) states that, "it is truly remarkable that it should be felt possible to understand the economy in terms of single representative individuals for households and firms." Financial economics has nullified macroeconomics (Lucas, 1987, p. 108; Davis, 2003, p. 35).

Aside from its faith in markets, individuals, and extreme forms of quantification, financial economics (as did Hayek) holds sacrosanct the liberal beliefs from an earlier epoch regarding the state -- "there is always too much government". Under neo-liberalism, this "small government" doxa remains firmly in place but the state itself is dominated by financial economic rationalities (Quiggin, 2012) based on the assertion that markets are superior to governments ${ }^{10}$. A variant of the belief in "small government" is that while there may be small "market imperfections" that these are best left alone, since, due to the systematic distortion of the policy process by interest groups, the costs of government intervention are greater than the costs of the market imperfections that government policies are supposed to remedy ${ }^{11}$.

While financial (or zombie) economics can be seen as one of the major ideological underpinnings of the contemporary neo-liberal symbolic universe, it would be a mistake to see the neo-liberal project as internally coherent. It is an, at times contradictory, work in progress with glaring paradoxes. In seeking to better understand some of neo-liberalism's contradictions; it is helpful to distinguish between its ideology (rhetoric), scholarship and its policy in practice. As Fine ${ }^{12}$ (2009), argues, each of these is shifting in content and emphasis across time and place. Whilst the ideology, scholarship and practice of neo-liberalism have connections with one another, these too are shifting and by no means mutually consistent ${ }^{13}$.

In summary, the theoretical basis of the neo-liberal symbolic universe for the past thirty years has been an extreme variant of economics which suffers from many flaws. Its rationalities took time to take hold. To constitute a symbolic universe, neo-liberalism needed to articulate with the key institutions of capitalism. One way in which this articulation occurred is through the models of financial economics developed in accounting and finance departments in universities (level 3 legitimation). MacKenzie (2006) writes that when the models of financial economics are incorporated into society's algorithms, procedures, routines and material devices, financial economics will have become "performative." In the case of financial models, they will be "performative" even if those who use them are sceptical of their virtues, unaware of their details, or even ignorant of their very existence. Accounting and finance provide a conduit through which financial economic rationalities are legitimated, implemented and become part of the symbolic universe. The next section considers how financial economic ideas became the dominant conceptual foundation for both accounting and finance academics as well as for professional accountants.

\footnotetext{
${ }^{10}$ Quiggin (2012) argues that this assertion has been empirically tested and proven to be false.

${ }^{11}$ As will be set out in the next section, Watts and Zimmerman (1986) follow this line of argument.

${ }^{12}$ See also http://eprints.soas.ac.uk/5443/1/coimbra.pdf7

${ }^{13}$ For example, neo-liberalism takes the ideological position of the glorification of the market and the demeaning of the state while in practice calling upon the state to rescue markets and provide an orderly environment in which markets can operate.
} 


\section{The new financial economic accountants.}

Academia plays a significant role in spreading and legitimating ideas. For this reason we turn first to the impact of financial (zombie) economics on academics. Interestingly, academic accounting and finance departments and business schools provided the incubators for the development of financial economic thought throughout the 1960s, 70s and 80s (MacKenzie, 2006). If the purveyors of financial economics wanted their theories to shape social practice, then, their early incubation in accounting and finance departments which have close association to practice, with hindsight, appears to have been an astute strategy. In any case, during the 1960s and 1970s, financial economics was viewed with distain in many departments of economics, although by the 1990s, financial economics had moved from the margins to the mainstream of economics (Mackenzie, 2006).

\section{Financial economics in the academic departments of accounting and finance}

Chabrak (2012) sets out in great detail the key figures and think tanks who worked hard over a long period of time to develop and disseminate their project. Early key figures that came to influence accounting thought and practice included Friedrich von Hayek, Henry Simons, Aaron Director and Milton Friedman ${ }^{14}$. Their project could have been considered to have its very early roots in 1937 when von Hayek met Director at the London School of Economics. These economists created institutions to develop and disseminate their ideas. Two key institutions were the Free Market Study and the Mont Pèlerin Society (MPS) which was founded by Hayek in 1947. Chabrak (2012, p 461) writes that the "MPS is distinctive because it was a secretive group, met annually/biannually, issued no findings or recommendations, and rejected taking part in any direct political action.... They elaborated a blueprint to rejuvenate liberal doctrine and to subtly and unobtrusively guide university curricula, media and political debate." The members of MPS were astute enough to understand that their project would take time to come to fruition ${ }^{15}$. Sister organisations to the MPS were set up around the world ${ }^{16}$. And academic institutions (notably, the universities of Chicago and Rochester) began to disseminate the neo-liberal ideas of the MPS. In this way, the neo-liberal project was buttressed and legitimated by influential universities. Forty chairs were created between 1974 and 1978 to promote neo-liberal pro-market values (Beder, 1998). Eight MPS members have been awarded the Nobel Prize for economics ${ }^{17}$.

Hayek's $(1945,1948)$ proposal that price mechanisms communicate information came to underpin the financial economics (Chicago and Rochester) school of accounting research. This influence can be discerned in Watts and Zimmerman's $(1978,1979,1986)$ generation of Positive Accounting Theory (PAT) and Jensen and Meckling's (1976) development of Agency Theory (Williams, 2004; Ravenscroft and Williams, 2009). Financial economics research in accounting gained credibility and recognition through two dominant academic journals -- Watts and Zimmerman's Journal of Accounting and Economics founded in 1979 and Jensen and Meckling's Journal of Financial Economics founded in 1976. Chabrak (2012, p 474) argues that the "success of PAT is attributed to its capacity to police accounting knowledge to maintain its elite reproductive order within the academic world" ${ }^{\prime 18}$. PAT was significantly bolstered by its ability to support the neo-liberal economic project alongside its ideological opposition to Keynesian (the New Deal and so on), market regulation and socialism (especially planned economies). Williams, (2004) and Ravenscroft and

\footnotetext{
${ }^{14}$ Chabrak (2012) notes that Director and Friedman were related by marriage

${ }^{15}$ This was not true of one of the sponsors. Chabrak (2012, p 462) notes that, "supporting a 20-year battle of ideas was much too long for its founders. Volker stopped funding the MPS in 1957".

${ }^{16}$ Chabrak (2012) notes that there are over 100 libertarian institutes in more than 70 countries (Blundell, J. (1999), Hayek, Fisher and The Road to Serfdom, available at: www.iea.org.uk/sites/default/files/publications/files/upldbook43pdf.pdf)

${ }^{17}$ Friedrich von Hayek (1974), Milton Friedman (1976), George Stigler (1982), James M. Buchanan (1986), Maurice Allais (1988), Ronald Coase (1991), Gary S. Becker (1992) and Vernon Smith (2002).

${ }^{18}$ This is achieved through these two journals and the American Accounting Association and its Accounting Review.
} 
Williams, (2009) point out that concepts such as morality, accountability, factuality, and wisdom in practice have been eradicated from the financial economics based accounting research agenda.

The economic context of the development of financial economic thought in accounting is important because it demonstrates that accounting technologies are adopted when it is in the interests of the most powerful to do so. For example, Jensen and Meckling's work was developed during the 1973 oil crisis $^{19}$-- a period in which large US corporations were facing considerable competition from Japanese companies. Their work was appealing in that it presented a theory which they said would render managers more "efficient" and which would make them act in accordance with the interests of shareholders. In Jensen and Meckling's work, following Hayek $(1945,1948)$, and consistent with financial economic theory, organisations were portrayed as a nexus of contracts between selfinterested individuals who contract for property rights to maximise their utility. In such a world, accounting has a contracting role to reduce agency costs in bond covenants and management compensation plans ${ }^{20}$. The policy implication of Jensen and Meckling's work was that in order to maximize wealth, firms should take on the characteristics of an "efficient market".

While Jensen and Meckling were proposing that accounting could be a useful management control/contracting tool, PAT accounting professors, with their financial economic doxa, which values unfettered and unregulated markets, were (and are) ambivalent towards the accounting profession and its accounting regulatory regime. For example, although Watts and Zimmerman have become the poster boys for a particular kind of accounting research, they are opposed in many ways to accounting standards and accounting regulation. Watts and Zimmerman's (1979) work makes a strong argument (again akin to Hayek's) against state intervention arguing that audited corporate financial statements were produced voluntarily prior to government mandate because corporate managers have incentives to contract to supply audited financial statements (Watts, 1977) ${ }^{21}$.

The anti-regulatory stance of Watts and Zimmerman is reinforced by their contention that selfregulating markets will not work if disturbed by standard-setting - especially standard setting which has been subject to political battles. Watts and Zimmerman state $(1979, \mathrm{p} 280)$ that they "assume that private citizens, bureaucrats, and politicians have incentives to employ the powers of the state to make themselves better off and to coalesce for that purpose. One way by which coalitions of individuals are made better off is by legislation that redistributes (i.e., confiscates) wealth." By singling out private citizens, bureaucrats, and politicians Watts and Zimmerman (1979) fail to acknowledge that large corporations, banks, accounting firms and so on also through their trade associations (and other organisations) resolutely set out to influence government policy (and are much more adept at doing so due to their financial power, family connections and so on). And Watts and Zimmerman's use of the term "confiscates" symbolizes their belief that wealth is created by capital is therefore diametrically opposed to Marx's labour theory of value. Making an argument which is strikingly analogous to Hayek's, Watts and Zimmerman (1986) argue that the Wall Street Crash provided politicians with an excuse to transfer resources to themselves by introducing accounting standards (GAAP), SEC rules, banking regulations and anti-trust policies to give the politicians control over resources. In effect Watts and Zimmerman argued that it is in the interests of politicians to manipulate accounting rules to ensure that they can take money from companies to use for their own purposes. Worse for the accounting profession, Watts and Zimmerman argued that politicians allow auditing firms to transfer wealth from their clients in the form of audit fees.

\footnotetext{
${ }^{19}$ The 1973 "oil price shock", along with the 1973-1974 stock market crash, have been regarded as the first event since the Great Depression to have a persistent economic effect -- Perron, P.; University, Princeton; Program, Econometric Research (1988) (PDF). The Great Crash, the Oil Price Shock and the Unit Root Hypothesis. Econometric Research Program, Princeton University Princeton, New Jersey. http://www.princeton.edu/ erp/ERParchives/archivepdfs/M338.pdf. Retrieved February 3, 2012

${ }^{20}$ Chabrak (2012) notes that this organisational theory is appealing because it is embedded in a particular belief about human nature (set out in agency theory) and within the ideology of capitalist private property.

${ }^{21}$ Watts and Zimmerman argue that an unregulated market serves as the most efficient controller of management because if managers do not maximise the value of company shares then individuals can sanction them by selling their shares.
} 
Furthermore, Watts and Zimmerman contend that standardisation restricts the set of available accounting procedures and so forces firms to adopt more costly contracting technology. Watts and Zimmerman believe that the form which accounting information takes should, dependent on the individual firm, be selected in order to fulfil an efficient contracting role.

The anti-regulatory stance of financial economics inspired accounting researchers has meant that much accounting research has concentrated on "testing the information content of accounting numbers" (in terms of bringing about a market reaction/change in share prices) especially after the introduction of new accounting standards ${ }^{22}$. This type of research was facilitated by contemporaneous improvements in computer technology. Very large databases have been used in this research, which confusing method with methodology, has been published with a scientific guise (Christenson, 1983). The narrow market information/investor concern of this research means that it fails to consider the macroeconomic consequences of accounting. For example, Arnold (2009) notes that there were a number of financial research papers on Fair Value accounting published before the financial crisis. These papers were concerned with the informational content of accounts which used fair value for capital markets rather than evaluating Fair Value's macroeconomic consequences. Arnold further notes that financial accounting research agendas are limited and ultimately shaped by the availability of quantitative databases. There is no publicly available empirical data on off-balance sheet entities, hedge fund activities, credit default swaps and other privately traded derivatives. Due to its micro economic focus aligned with the problems of collecting data, too much accounting research appears to be oblivious to the most socially important aspects of accounting practice, for example tax evasion, insolvency, money laundering, fraud and so on. In short, most accounting research is fixated on teasing out the types of accounting information which is useful for investors in that it provokes a share price movement.

A parallel and overlapping development of financial economics occurred in the discipline of finance indeed there is a significant overlay between markets-based accounting research and finance. The models developed in finance were deliberately simplified so that they could take a simple mathematical form. These models were frequently at odds with reality (for example, the presence of a risk free asset, no transactions costs and so on). Mackenzie (2006) notes that this did not concern economists like Friedman (1953). Friedman argued that models should not be judged according to whether their assumptions were empirically accurate -- their purpose is to make accurate predictions.

Positive accounting (financial economics) ideas and models have been transferred to the accounting profession by academics who operated on both the field of academia and professional practice. Rochester and Chicago school graduates would come to staff the accounting profession, the media, think-tanks and so on. The same happened in finance. MacKenzie (2006) writes that attractive consultancies and tempting job opportunities were available to academics from the 1960s onwards in the finance sector. Fischer Black resigned his professorship at MIT for a post at Goldman Sachs. Scholes became a consultant to Salomon Brothers and later became a joint head of their group that traded and sold derivatives.

In summary, this section briefly outlined the development of financial economic ideas in accounting and finance departments and the consequent implications for accounting research. In particular, the anti-regulatory stance of positive accounting researchers was highlighted. It is on the question of regulation that there is a stark contradiction between mainstream accounting academia and the accounting profession. The "response" of the accounting profession to the anti-regulatory stance of financial economic thought alongside its contemporaneous adoption of financial economics as its conceptual base is discussed next.

\footnotetext{
${ }^{22}$ Perhaps the seminal paper here is Ball and Brown (1968).
} 


\section{Professional financial economic accountants}

The accounting profession, concurrently with the rise of financial economics in accounting and finance academia as outlined above, began formalising its conceptual base in the mid-1970s in the US, through FASB's first “Conceptual Framework" project. Hines $(1989, \mathrm{p} 72)$ writes that Conceptual Framework projects are used as a political resource in the professionalisation struggle during times of possible intervention by the state and at times of competition from other groups (see also Bryer, 1999b; Robson, 1999). Zhang and Andrews (2014) found the same motivations underpinning the most recent (and on-going) IASB/FASB Conceptual Framework project which was initiated as a strategic response to threats to accounting legitimacy in the form of significant criticism for its role in the recent financial crisis. At the time in which Hines was writing (in the late 1980s) it was clear that Conceptual Framework projects were doomed to "technical failure" and that the major rationale for undertaking Conceptual Frameworks was not functional or technical but a strategic manoeuvre for providing legitimacy to standard-setting boards and the accounting profession (Hines, 1989). It was in the interests of the accounting profession, under a powerful ideological attack from the Chicago School, to articulate accounting regulation to "market requirements" According to financial economics, this would mean moving away from a stewardship perspective towards a perspective which was concerned with the provision of information about future free cash flows for investors.

Although zombieconomics is a useful analogy, unlike the instantaneous change from human to zombie in popular culture, ideological change occurs sometimes very slowly and that for significant periods of time, vestiges of previous understandings remain. The, initially subtle, changes in accounting could perhaps be best summarised as a move from accounting having a stewardship function (a more traditional macroeconomic approach) towards an informational perspective on financial reporting. This was set out in the Accounting Principles Board (APB), Statement number 4 in 1970, which stated that the "basic purpose of financial accounting is to provide information that is useful to owners, creditors and others in making economic decisions" (APB, 1970, paras 40 and 73). The APB statement no 4 was reiterated later by the Trueblood Committee, although its report did maintain an idea of stewardship this appeared under the umbrella term accountability. And the successor to the APB, the Financial Accounting Standards Board's (FASB) first Conceptual Framework Project made user needs a primary objective of financial reporting. In its Statement of Financial Accounting Concepts, No 1 (1978), it states:

Financial reporting should provide information that is useful to present and potential investors and creditors and other users in assessing the amounts, timing, and uncertainty of prospective cash receipts ... Since investors and creditors' cash flows are related to enterprise cash flows, financial reporting should provide information to help investors, creditors and others assess the amounts, timing, and uncertainty of prospective net cash flows to the related enterprise. (page viii)

Accounting's newly emerging concern with the provision of information for investment decisions meant that it was to look to the future rather than the "transactions base" of the past. The accounting profession described "usefulness" in terms of the provision of information for market participants and this set in motion a gradual shift towards accounting technologies designed to place a value on expected income alongside an emphasis on "the market" ${ }^{24}$. Those who developed these accounting technologies drew their inspiration from a Friedmanite vision of expectations being

\footnotetext{
${ }^{23}$ Chabrak (2012, p 472) argues that neo-classical economists "embraced statistics and the mystique of science thus became one of the major neoliberal calling cards of the Chicago School" (Van Horn and Mirowski, 2009, p 163).

${ }^{24}$ Although individual accountants have practical difficulties with this approach, for example, the auditing of fair-value accounting (SmithLacroix et al., 2012).
} 
reduced to a micro-level domain of knowable outcomes with attached probabilities. Thus the "revolution" (Beaver, 1989) in accounting led it into a world of what Marx would describe as "the fictitious" (see also Casson and Napier, 1997, cited in Power, 2010) and proved to be slippery slope to what Power (2010) describes as a balance sheet approach to accounting in which the balance sheet components (which according to financial economics, if recorded at fair value, will be able to give information about the future) have become meaningful rather than residual values.

In summary, financial (zombie) economic rationalities have come to dominate accounting practice, conceptual frameworks and scholarship. These rationalities evolved in a period of economic downturn and part of their appeal was their promise of providing a blueprint for efficient and profitable organisations and information to investors about future cash flows. The influence of financial economic theory on accounting research meant that, with its microeconomic frame, accounting research failed to see the looming economic crisis and it has failed to critically consider the broader social, economic, or political implications of accounting practice. According to neoliberal economic rationality accounting has two dominant functions. One is to monitor, measure and report on the performance metrics in inter and intra organisational contracts. The second is to provide (preferably unregulated) accounting information to enable investors to assess future cash flows. Importantly, akin to the way in which financial economics impacted upon accounting practice, MacKenzie (2006), drawing upon Callon's claim that economics itself is part of the infrastructure of modern markets, argues that financial economics did more than analyse markets it altered them. In effect, Mackenzie argued that financial economics altered the trajectory of financial markets. Both accounting and finance technologies have helped to construct as well as reflect contemporary capitalism (see also Hines, 1988). The next section considers the contemporary context in which finance capital tends to dominate industrial capital - financialisation.

\section{Financialisation}

The term financialisation remains ill-defined. But for the purposes of this paper it includes the globalisation of financial markets, the rise in income from financial investment, the shareholder value revolution (Clegg et al, 2011) and the penetration of finance across all commercial relations to an unprecedented and direct extent (Fine, 2007b; Fine, 2008; Stockhammer, 2004). Under neoliberalism all markets are highly valued, but, in the contemporary period, the markets given the greatest priority are those of finance. This new dominance trailed regulatory, technological and economic changes. A key regulatory change was the 1971 abandonment of the Bretton Woods agreement which allowed the free determination of interest rates and fewer quantitative controls over financial institutions. Technology changes (especially in terms of computing and electronic information transfer) in the same period had a profound impact on the international financial system. Economic change in the form of the 1973 oil crisis severely weakened industrial capital. Financial capital during this period developed an unrivalled dynamism; it became sexy.

It is beyond the scope of this paper to do justice to the linkages between financialisation and neoliberalism. Different writers see different linkages between the two. Some link the rise of neoliberalism to the growing role and power of finance in the political economy of capitalism. For example, Dumenil and Levy (2004, 1-2), argue that "...neoliberalism is the expression of the desire of a class of capitalist owners and the institutions in which their power is concentrated, which we collectively call 'finance,' to restore ... the class's revenues and power..." While others (Kotz and McDonough, 2010), see financialisation as part of the cyclical nature of capitalism. Kotz and McDonough (2010) argue that an earlier form of financial dominance arose in the late nineteenth/early twentieth centuries, and consequently they see an expanding role for finance in economic activity as part of a periodic change in the capitalist institutional structure. Of course it is possible that financial capital is involved in a project to "restore" class power and that financialisation is cyclical. 
The contemporary expansion of finance capital is mainly unrelated to expansion of lending to industrial corporations for purposes of investment and production (Fine et al, 1999). In part, financialisation has meant the proliferation of purely financial markets and fictitious capital instruments, some of which do not bridge to real activities. However, financialisation's reach extends beyond the realm of corporate finance. For example, it has impacted upon the natural environment with futures trading in carbon-offsets ${ }^{25}$ (Fine, 2008) ${ }^{26}$ and, as we will see next, individuals have become "financialized".

Neo-liberal economic rationality which sees the state's role solely as providing the conditions to allow markets to flourish has made it virtually illegitimate for the state to involve itself in economic interventions to promote full employment or other policies which enabled the post-war boom ${ }^{27}$. At the same time, many state safety-nets have been removed. These policy changes have forced citizens into their own private financialized worlds such that the financial economic idea of rational expectations in which individuals optimise by modelling the economy has become a stark and painful reality (Bay, 2011). The removal of collectivised state social provisions means that many risks ${ }^{28}$ have been transferred to citizens who have had to suddenly make their own provision for financial security, children's education, housing, social care, and capacity to survive unemployment or illness; at the same time, collective provision through trade unions has been discouraged (Wilby, 2009). This placing of risk onto the individual has made them into two-legged cost and profit centres (Blackburn, 2006) in search of the best financial deals. Deregulation and internet search engines mean that individuals have to search for the cheapest car insurance, mortgage, utility prices, savings accounts and so on. Even everyday consumption has become a game of risk (Martin, 2002). "Buying an airline ticket, booking a hotel, buying petrol, all involve risk management ploys with the best deals going to the savvy market players, the clever risk takers" (O'Neill, 2008, p 9). For many workers, without enough money for the essentials of life, borrowing (frequently at immorally high rates of interest) has become the norm and so interest rate risk is unavoidable (Elliott and Atkinson, 1998). The transfer of pension provision from defined benefit to contribution schemes has meant that millions will be dependent on the price of stocks and bonds to enable them to retire.

Financialisation means that individuals behave like businesses, businesses like banks and banks like hedge funds (Blackburn, 2006). "Failure" (homelessness, unemployment, and death through lack of the money for health care) is seen as the fault of the individual rather than caused by any wider social or economic force (Martin, 2002) ${ }^{29}$. And yet, the elimination of employment opportunities, through company strategic decisions to maximise their current share price, by for example, the introduction of zero-hours contracts, mass redundancies and so on, is an important ideologically driven mechanism of financialisation.

The "maximization of shareholder value" is a guiding principle of financialisation. The institutional setting for this is that a significant majority of shares are owned by institutional investors and the vast majority of share trading $(70+\%)$ arises from companies using high-frequency trading strategies. These types of shareholders are looking for short term share-price increases. This means that "the restructuring of productive capital is sacrificed for realisation of short-term gains or shareholder

\footnotetext{
${ }^{25}$ Fine makes the point that "Commodity fetishism has surely arrived at perfection when we can buy and sell in a market for not producing something in the future (especially when, in fact, carbon trading is about allowing that undesirable carbon to be produced for you by someone else as well as yourself on the grounds that they might produce less of it than you would if you were producing what they produce as well as what you yourself will carry on producing)."

${ }^{26}$ Some of the social consequences of financialisation are horrendous. Fine (2008) gives the example that hundreds of millions of people are more at risk from starvation because of trading in commodities futures.

${ }^{27}$ Stiglitz (2002) argues that the vested interest and ideology of finance lie behind poor policy

${ }^{28}$ It is beyond the scope of this paper, but for those interested, an interesting debate surrounding risk from the perspective of both capital and labour can be found in Harney (2010) and Toms (2010).

${ }^{29}$ The individualising of failure has a long history in the US, as was charted by Sandage (2005). Arthur Miller commenting on Sandage (2005) stated that, "I found Born Losers a confirmation of an old belief that in American history there is a crash in every generation sufficient to mark us with a kind of congenital fear of failure." (see http://www.history.cmu.edu/faculty/sandage.html)
} 
value" (Fine, 2008b). Management, through the reward of share options, are incentivised to maximize shareholder value in the short term, by any means possible, even if this means shrinking productive capacity. As Fine (2008b) writes, Rossman and Greenfield (2006, p 2, italics added) citing Stockhammer (2004)--

Of course, companies have always sought to maximize profit. What is new is the drive for profit through the elimination of productive capacity and employment. Transnational food processors, for example, now invest a significantly lower proportion of their profits in expanding productive capacity. Financial markets today directly reward companies for reducing payroll through closures, restructuring and outsourcing. This reflects the way in which financialization has driven the management of non-financial companies to "act more like financial market players".

A broader macroeconomic analysis would show that the pursuit of shareholder value maximisation could mean that the system is killing itself. It is doing this on many different fronts. It is severely shrinking its own pool of customers (Stout, 2012). And some companies are buying back their own shares in order to increase shareholder value at the expense of long term investment in the company (see for example, Lazonick et al, 2013). Non-financial companies have been accruing increasing proportions of their profits from financial activity (Clegg et al, 2011). Stockhammer (2004) using data from the 1960s to the 1990s argues that financialisation explains the entire slowdown in accumulation in France and a third of the slowdown in the US. It has created a dynamic in which real accumulation is both tempered and, ultimately, choked off by fictitious accumulation.

In summary, while financialisation, what it is, and its roots are nebulous, it is clear that the globalisation of financial markets, the shareholder value revolution, and the patterns of institutional shareholding and their trading strategies has had profound detrimental effects on individuals and on economic activity. Finance capital also contributed to the recent crisis in other ways. In the search for profitable returns, new and sophisticated financial instruments have been created by financial institutions which are increasingly removed from the value creation process. Since money flows to where it can earn the greatest returns, investments have been made in a myriad of forms of fictitious capital, rather than in the real economy (Harvey, 2006, p 254). Harvey (2006) explains that Marx's primary purpose in his discussion of fictitious capital is to disabuse us of the idea that a marketable claim upon some future revenue is a real form of capital. He wishes to alert us to the insanity of a society in which investment in fictitious capital appears just as important as investment in real capital (production). The next section deals with the role of fictitious capital and financialisation in the recent crisis in more depth.

\section{The growth of fictitious capital and the recent crisis}

While Marx could perhaps not have envisaged the exact forms of fictitious capital which were likely to emerge in the $21^{\text {st }}$ century, the idea that fictitious capital should be distinguished from "real" capital which is capital invested in the means of production enables an understanding of the risks which lie behind the activities of banks and financial institutions at the end of the $20^{\text {th }}$ and beginning of the $21^{\text {st }}$ centuries. Contemporary forms of fictitious capital are traded through many different markets with varying degrees of regulation and include stocks and shares, bonds, derivatives ${ }^{30}$, collateralized debt (or loan) obligations and numerous other asset classes ${ }^{31}$ and financial instruments. Deutsche Börse AG (2008) explains that the number of OTC-traded derivatives is unlimited in principle as they are customized and new contracts are created continuously. A broad

\footnotetext{
${ }^{30}$ These can be traded on derivatives exchanges but also bilaterally between market participants. The latter segment - i.e. the OTC segment - currently accounts for around 84 percent of the derivatives market and operate with almost complete disregard of national borders.

${ }^{31}$ For example the securitized future gate receipts at Manchester United.
} 
universe of exchange traded derivatives exists as well: for example, over 1,700 different derivatives are listed on the three major global derivatives exchanges. ${ }^{32}$ The derivatives market has grown significantly - around 24 per cent per year from 1995 until 2008 - into a global market with about $€ 457$ trillion of notional amount outstanding ${ }^{33}$. By this measure, the derivatives market is more than four times larger than the combined global equity and bond markets measured by market capitalization $^{34}$.

Until 25 years ago, the derivatives market was small and domestic and mainly served the function of risk hedging. The derivatives market emerged at the time of the end of dollar-gold convertibility in 1971 at which time, currency values, especially for the dollar, became much more volatile (McNally, 2009). Early derivatives served as a response to the risks confronting capital due to volatile currency markets. For example, a UK exporter of goods to the US, could take a short position for the amount they are due to receive in order to hedge their foreign exchange risk ${ }^{35}$. As in an earlier capitalist period, modern fictitious capital has played an important role in the capital accumulation process. But while early derivatives contracts had the function of eliminating risk, many later became purely speculative (McNally, 2009), or as Deutsche Börse (2008) put it, the wide variety of derivative contracts "allow innovative investment strategies" ( $p 4)$.

An excellent example of a form of fictitious capital which can play a useful role in the capital accumulation process but also provides a source of vulnerability is a Credit Default Swap (CDS). A CDS is essentially an "insurance policy" taken as a protection against default by a borrower. The danger lies in "naked CDSs", which can be purchased by those who are not owed any money (for example if they do not own the bond). Thus it is possible to "bet" on a company, in which you have absolutely no interest, defaulting on its debt. Naked CDSs account for $80 \%$ of the CDS market but they create terrible incentives. For example, following Shaxson (2013), it is entirely possible for a Private Equity Company to borrow money to take a controlling interest in a (let's say) clothing company, then dramatically cut costs by whatever means possible (cutting wages, avoiding pension obligations, sweating assets and so on); the consequential enhanced cash flow projection can be taken to a bank and borrowed against. If, the bank is prepared to loan (say) $f 3 m$, the Private Equity Company can take the whole $£ 3 \mathrm{~m}$ cash as a "bonus" and not invest any of it in the clothes company although the debt will belong to the clothes company and not the Private Equity Company. At this stage the Private Equity Company could also purchase a naked CDS on the clothes company while continuing to syphon off as much money from the company as possible, including not paying any tax. The heavily indebted, demoralised company may then collapse. Aside from the $f 3 m$ bonus and any other money siphoned from the company, the Private Equity Company will be able to profit from the collapse through the naked CDS. If this occurs in the UK, in all likelihood any tax owing will never be paid since the taxation authority would be an unsecured creditor. This is unproductive rent extraction (Shaxson, 2013 provides similar examples).

While there are many different forms of derivatives ${ }^{36}$, the global financial structure started to crumble when a particular form of derivative (Collateralized Debt Obligation) was impacted by some of the other outcomes of financialisation -- falling wages levels, the choking off of real accumulation

\footnotetext{
${ }^{32}$ Chicago Mercantile Exchange, Eurex and Euronext.Liffe

${ }^{33}$ The Global Derivatives Market: An Introduction -Deutsche Börse AG (Apr 2008)

${ }^{34}$ However, the estimated gross market values of all derivatives outstanding total only $€ 10$ trillion, which is much lower than the equity ( $€ 43$ trillion market capitalization) and bond markets ( $€ 55$ trillion market capitalization).

${ }^{35}$ So, for example, if a British Export Company is due to deliver goods to a US customer and be paid US\$1,500 in six months' time, it might enter into a derivatives contract in which it agrees to sell US\$1,500 at a rate of US\$1.50= $f 1$, thereby ensuring that it will receive a certain $£ 1,000$ when the goods are delivered.

${ }^{36}$ It is also possible to purchase weather derivatives offering compensation if temperatures at a specified location exceed or fall below a predefined reference temperature. While this type of derivative might serve to reduce the risk of a highly specialised farmer, arguably, it exemplifies the speculative nature of many derivatives. The vast majority of derivatives are tremendously risky - and their level of risk is extremely difficult to measure.
} 
and unemployment. Collateralized Debt Obligations (CDOs) became popular around $2000^{37}$ and were seemingly less risky than other derivatives because they were backed by assets (people's homes). In spite of the potential for a collapse in the housing market (for example, because of falling real incomes in the US), the credit rating agencies ${ }^{38}$ failed to adequately reflect the risks associated with many mortgage-backed CDOs. After months of negotiations with JP Morgan the bank which devised CDOs they were awarded the highest possible grade (Tett, 2009). Many CDOs consisted of subprime mortgages and offered higher rates of return aligned to a "safe" credit rating. Clegg et al (2011) note a central flaw in the CDO scheme, that appears to have been totally missed by the highly paid bankers and credit rating agencies, which is that in the sub-prime mortgage market defaults will in all likelihood be synchronised. This makes CDO failures very different from corporate sector failures which typically take place at different times for different reasons.

The first signs of the looming crisis appeared in the US when there was a rapid increase in mortgage delinquencies and foreclosures and CDOs became worthless. ${ }^{39}$ What is perhaps unique to the recent crisis is that families and individuals were more quickly and intimately hurt by the crisis than ever before because of "personal-financialisation" (as explained earlier). The crisis did not just spread to households through unemployment but through low wages. So demand fell very quickly exacerbating the crisis.

A Marxist definition of an economic crisis, as Harvey $(2006,2011)$ sets out, is a situation in which surplus capital and surplus labour exist side by side with seemingly no way to put them back together ${ }^{40}$. He called this "over-accumulation". Kunkell (2011) points out that in the US, corporations are sitting on almost two trillion dollars in cash while unemployment hovers just below 10 per cent (Kunkel, 2011). In other words investors (perhaps because they are looking for shortterm profits - or shareholder value maximisation) are not investing in opportunities, which will create new jobs (Harvey, 2011) and so create a demand-led recovery ${ }^{41}$. In the recent crisis, alongside over-accumulation, we also have had over-financialisation. The crisis has been exacerbated by the speculative bubble in certain derivatives and other extreme forms of fictitious capital (Harvey, 2006). At this stage it is important to note that, while it might appear as if the origin of the 2008 crisis was financialisation and the new insane forms of financial manipulations, crises are relatively concrete phenomena which reflect the deeper, more abstract, contradictory character of capitalist economic relations (Fine et al, 1999).

Marx demonstrates that they are surface froth upon much deeper currents making for disequilibrium. ... The difficulty here is to disentangle the pure surface froth of perpetual speculation from the deeper rhythms of crisis formation in production. (Harvey, 2006 p 325)

Thus whatever forms a capitalist crisis takes there are common problems which occur. There is the persistent contradiction that individual companies try to reduce their wage bills while hoping that other employers pay sufficient wages to enable people to buy their products. And once a crisis

\footnotetext{
${ }^{37}$ Tett, 2009, provides an extraordinary account of the development of CDOs from the perspective of the bankers who devised CDOs at JP Morgans.

${ }^{38}$ Butler (2009) argues that credit rating agencies and auditor's fees are paid by directors and traders who are motivated to hide bad news and credit risk. They may maximize their fees by giving assurances too liberally.

${ }^{39}$ Joint Center for Housing Studies of Harvard University, THE STATE OF THE NATION'S HOUSING (2008)

${ }^{40}$ Labour availability is no problem now for capital, and it has not been for the last 25 years. But disempowered labour means low wages, and impoverished workers do not constitute a vibrant market. Persistent wage repression therefore poses the problem of lack of demand for the expanding output of capitalist corporations. One barrier to capital accumulation - the labour question - is overcome at the expense of creating another - lack of a market. (Harvey, 2006, pp)

${ }^{41}$ In the short-run people maintained a certain standard of living by borrowing. According to a recent Citizen's Advice Bureau factsheet, total personal debt in the UK currently stands at $£ 1.46$ trillion. The average household debt in the UK is $£ 8,920$ (excluding mortgages). This figure increases to $f 18,583$ if the average is based on the number of households who have some form of unsecured loan (www.citizensadvice.org.uk/pdf_the_value_of_debt_advice.pdf accessed 20th October, 2011)
} 
begins, and individuals and companies are unable to make interest and other payments, they will be forced to sell their assets cheaply. Even profitable businesses can be forced to close due to tightening credit. In this way, a crisis in the "fictitious economy" can spread to the "real economy" (McNally, 2009). Marx states that a crisis involves a destruction of capital. The "values" of fictitious capitals - all kinds of paper assets - which were previously treated as if they were real assets become, as stated earlier, worth as much a losing book-maker's betting slip. At the same time, real capital is destroyed as companies go into liquidation (McNally, 2009) ${ }^{42}$.

A further concern with modern day capitalism, even in times of stability, is that investors pursue "high private returns", not "high social returns" (Kunkell, 2011). And speculative bubbles can occur rather than investment in things which society needs. As Stiglitz (2010) observes "The world is currently faced with serious challenges that also present investment opportunities: retrofitting the world economy to face the challenges of global warming, or making the investment necessary to reduce global poverty. There is no shortage of opportunities for investments with high social returns." But, some investors deliberately chose to invest in things with negative social returns through speculative attacks. The "objective of a speculative attack is to generate profits for the speculators, regardless of the cost to the rest of society. They can make money by inducing panic and then feel pleased with their 'insight': their concerns were justified, but only because of the responses to which their actions gave rise" (Stiglitz, 2010, p 17). This explains why some derivatives traders and investors (for example those investing in naked credit default swaps) will become very rich when companies fail. They therefore benefit from the misery of the individuals who have lost their livelihoods. Indeed some speculators gamble on this very thing.

This section set out the scale of the growth of fictitious capital in the run up to 2008. It argued that while some forms of fictitious capital were intended to reduce risk, others introduce significant risk into the system. However, risky derivatives were not the sole cause of the banking crisis. Earlier in the paper it was argued that most accounting research is unable to comprehend or investigate the broader social and economic implications of market activity. Nevertheless organisations do have to produce financial statements. Fine $(1999, \mathrm{p} 73)$ states that "while industrial accumulation is confronted with a predatory and destructive explosion of financial accumulation, international authorities limit themselves to mealy-mouthed platitudes about transparency and accountability of financial institutions." In market economies the ideological mantra of equality, freedom and fairness is profound, as is the belief in professions which will, articulated to this ideology, act in the public interest and render organisations accountable. Under financialisation the accounting profession with its financial economics conceptual base has served its own interests (as well as those of its paymasters) by providing accounts which act as a transparency and accountability veil. Arnold (2009, p 804) explains that "financial reporting rules governing off-balance sheet structured investment vehicles (SIVs), including rules on special purpose entities (SPEs), qualified special purpose entities (QSPEs) and variable interest entities", were significant in the recent crisis. In effect, accounting rules were complicit in the creation of a shadow banking system. Although accounting information is important since it is part of the legitimating structures of society, it is more than just ideological - it is a technology. In the next section we turn to the role of accounting standard setters and accounting technologies in the financial crisis.

\footnotetext{
${ }^{42}$ The situation is exacerbated by the unequal distribution of pain, reflecting the unequal distribution of gain in better economic times. Those with the least power (and the highest marginal propensity to consume, and thus more likely to help regenerate the economy) fare worst. While it is beyond the scope of this paper, this insight demonstrates the psychosis of the current austerity measures.
} 


\section{Accounting and the financial crisis.}

In this section it will be argued that the context in which the accounting profession operates is important for analysing accounting's complicity in the crisis. Accounting standard setters are subject to significant pressure by their various paymasters and the accounting profession and its various sub-fields (auditing, standard setting and so on) are in a constant battle to maintain their structural position in the field of business and vis-à-vis the state, especially since the financial crisis (Bengtsson, 2011). The institutional domain of accounting standard setting is considered first.

\section{Accounting regulation -private and international}

An essential feature of the accounting standard setting regime in the $21^{\text {st }}$ century is that it is private and increasingly international in character ${ }^{43}$. Nölke and Perry (2007) argue that the adoption, in July 2002, by the European Parliament and the Council of the European Union (EU) of a regulation requiring more than 7,000 EU stock exchange-listed companies to use International Accounting Standards (IAS) and International Financial Reporting Standards (IFRS) was one of the most wideranging delegations of public authority to a private, business-funded, and business-led, body within international politics (Nölke and Perry, 2007). Although the state has not been totally usurped by private international accounting standard setters since each standard only becomes binding when endorsed by, depending on the jurisdiction, a state sector body (see also Arnold and Sikka, 2001). More recently the EU forced the IASB to change its rules for certain aspects of hedge accounting as a direct result of pressure from banks. As a result there are two versions of IAS 39 (EU version and IASB version). Nölke and Perry, $(2007, \mathrm{p} 1)$ state that "(N)evertheless, within these qualifications the IASB ${ }^{44}$ is still one of the most amazing cases of delegation of authority to a private body in international politics." In practice, it would be extremely difficult in a globalised world for any country not to adopt either US or international accounting standards. For example, without these accounting standards in place, it would be difficult for any country to attract inward investment or IMF and World Bank loans. It is beyond the scope of this paper to discuss this but International Accounting Standards present a contradiction. While neoliberal fundamentalists argue for less rules and regulations, in the current neo-liberal period, accounting rules have become ubiquitous through international standards ${ }^{45}$.

Although they have become international, accounting standard setters and the accounting firms that oversee standard application are constantly fighting to maintain and enhance their position (Bourdieu and Wacquant, 1992) ${ }^{46}$ and are under pressure from fractional interests. They "walk a tightrope" in that they have to please their paymasters while at the same time appearing to make rules to "police their paymasters" in order to maintain their legitimating role. This balancing act has proved problematic for accounting professionals. There is always the potential for new bodies to enter the fray to usurp the lucrative market for accounting services. For example, Power (2010) notes the re-emergence of the International Valuation Standards Council (IVSC) in 2009. The IVSC criticised the IASB exposure draft on fair value measurement for being too narrowly prescriptive about the range of possible valuation methods arguing that the IASB should restrict itself to principles leaving space for the development of detailed valuation methods (IVSC, 2009). If the IVSC's pronouncements better serve the interests of IASB's paymasters, the IASB could find itself increasingly replaced by a more "friendly" body. In a study of Canadian auditors, Smith-Lacroix et al (2012) found that auditors needed the support of valuation specialists when trying to audit fair value

\footnotetext{
${ }^{43}$ Cooper and Sherer (1984) described the non-neutral role of standard setters at a time when arguably standard setters were more under the control of the state, or at least were more contained within national boundaries.

44 International Accounting Standards Board

${ }^{45}$ Accounting standards enable the market system. Mark to market is used when prices are high (attracting more gamblers). When there is a market down-turn, mark to market allows companies to fix the price. This means that losses are limited so avoiding the disappointment of market players.

${ }^{46}$ As in any field, the accounting field is rife with on field battles. For example, in the UK after the financial crisis the House of Lords set up an inquiry to examine the impact of the lack of competition in the audit market and scrutinise the role of the Big 4 . Potential competitor firms to the Big 4, like BDO, gave evidence against the Big 4.
} 
accounting numbers. Perhaps, unsurprisingly, the uncertainty has proved to be rather lucrative for accountants - enabling them to earn higher fees. The field of accounting has become rather unstable. It is possible that large accounting firms (like the big 4) might "decouple" themselves from traditional standard setters if "principles" prove to be more profitable than detailed rules. And, international accounting standard setters are increasingly becoming decoupled from their professional base (the professional accounting bodies donated symbolic capital by various nation states) (Power, 2010). The loss of the symbolic capital of "professionalism" is a threat to the power of accounting bodies (Ramirez, 2001, Walker, 2004). The financial crisis and the criticism of the accounting profession's information provision, standards, and auditing exacerbated this threat to the legitimacy and symbolic capital of the profession (for example, Gup and Lutton, 2009; Krumwiede, 2008; Laux and Leuz, 2009; Sikka, 2009).

In summary, accounting regulations of international scope are set by privately funded organisations. This means that there is always the possibility that funding could be withdrawn and/or new bodies could emerge to oust the extant accounting regulators. Aside from the embedded ideology of neoliberalism, the institutional context of accounting regulation makes it likely that accounting technologies will be produced which accommodate the interests of business. The implications of this section in terms of understanding accounting's role in the crisis is that the institutional structures of accounting standard setting mean that the kinds of rules needed to help regulate markets and curtail some of the more dangerous forms of speculation so desperately needed before (and since the crisis) can never be forthcoming. The financial economic rationalities embedded in the professional conceptual frameworks of the accounting profession will have blinkered it to the havoc created by neo-liberalism and financialisation everywhere except in markets; in the case of havoc being wrought in markets measures are being taken, for example fair value accounting can be dropped (see further discussion below). And even if accounting standard setters feel an obligation to "society in general", their funding would be removed if they failed to develop standards which legitimize, sustain and enable financialisation. Accounting has long been a technological facilitator for capitalism. The paper now turns to the more technical aspects of accounting.

\section{Accounting technologies and the financial crisis}

Accounting's entrenchment in the economic system meant that in many ways, accounting played a similar role in the recent crisis as it did in earlier ones ${ }^{47}$. Marxist theory would argue that accounting technologies play a key role in the control of labour and the extraction of surplus value from labour by increasing productivity and reducing wages and so are part of the creation of a "crisis of overproduction" in which there is an excess of production (supply) and inadequate demand. Bryer (2006b) uses Marx's theory of the labour process to argue that accounting is the premier control system because it provides senior managers with "objective" measures of the generation and realisation of surplus value (see also Armstrong, 1985; Marsden, 1998) ${ }^{48}$.

The very poor quality of financial accounting was also a feature of the crisis. For example, in the weekend before the demise of Lehman Brothers, the bankers and regulators working in the headquarters of the New York Federal Reserve, were reportedly told by one of Lehman's bankers, "We have no idea of the details of our derivatives exposure and neither do you." (Guerrera and Bullock, 2008). The accounting rules regarding derivatives were clearly problematic. In the run up to the crisis, the accounting rules which allowed some assets to be shown at cost, others at fair value and others not at all (through structured investment and other vehicles) meant that financial

\footnotetext{
${ }^{47}$ The links between capitalism and accounting are profound Chiapello (2007) argues that capitalism, and double-entry bookkeeping practice, which highlights and sustains the circuit of capital, are inextricably linked. She further argues that the philosophy of capitalism is entrenched in accounting.

${ }^{48}$ Accounting technologies too were a key feature of other facets of the neo-liberal project, for example privatisations (see for example, Arnold and Cooper, 1999; Cooper and Taylor, 2005).
} 
institutions were accounting on an "inconsistent basis" ${ }^{49}$ and the accounting rules made it fairly easy for financial institutions to hide their losses (Butler, 2009). Accounting also enabled what has come to be described as a "cookie jar" approach to reporting profits and losses which allowed companies to hide and release profits in order to reduce volatility, thus making companies appear less risky. For example, the Office of Federal Housing Enterprise Oversight produced a report on accounting irregularities at Fannie Mae. This report revealed that the management of Fannie Mae wished to promote the image that it was a "low risk" enterprise that made substantial profits. So in profitable years the company would create artificial provisions that would reduce profits and in loss making years would release these provisions. Aside from hiding the significant risks the company was taking, this accounting tactic benefitted management who took bonuses for meeting profit targets every year rather than for only the "genuinely profitable" years.

This section argued that accounting technologies in general contributed to the crisis. Management accounting technologies contribute to the crisis tendencies of capitalism through their drive to reduce wages. And In the run up to the crisis the erroneous financial accounting signals were produced by financial institutions aggravated the tendencies towards disproportionality and overaccumulation ${ }^{50}$. While other facets of accounting contributed to the crisis, the aspect of accounting which has come under most scrutiny since the crisis is fair value accounting. The growth of derivatives placed increasing pressure on accounting standard setters to develop new standards and was the catalyst for the expansion of "fair value accounting" (FVA) (Power, 2010). In practice, the speed and magnitude of the creation of derivatives meant that accounting standard setters were a few steps behind the increasingly avaricious, powerful and "innovative" finance industry (Davenport, 2004). The next section discusses this further.

\section{Accounting standards for derivatives and fair value accounting}

Although fair value accounting which privileges market values is ideologically consistent with financial economics, it was not a new technique having it origins as early as 1800 in French and German accounting regulation especially with respect to inventory valuation (Richard, $2005^{51}$ ) and the 1930s in the US (Cascini and DelFavero, 2011). Fair value as a term was typically used by accountants in the 1970s to mean the total amount of (revalued) net assets of a company, in the case of a merger or acquisition, for the purpose of calculating goodwill. The first major step towards implementing FVA in its contemporary form, occurred in December 1975, as the FASB issued Statement of Financial Accounting Standard No. 12 (FAS12) (Cascini and DelFavero, 2011). This was the first time that, the FASB allowed companies, to report unrealized losses and unrealized gains on marketable securities in income ${ }^{52}$. This was a significant turning point since it legitimated and institutionalised a practice which would come to enable the speculative bubble and which was associated with one of the key popular concerns of the banking crisis - executive pay. Companies in the finance industry do not have to wait until a financial product is sold before they can recognize a profit. This is consistent with the balance sheet approach. A hedge fund manager can calculate the difference between the original purchase price and the fair value of a product to determine their profit and hence their bonus.

The FASB began working on a standard for derivatives around 1992, and took several years to come up with one. When large financial institutions didn't like their proposal, they tried to have FASB

\footnotetext{
${ }^{49}$ Of course this is ideologically consistent with the financial (zombie) economic doxa that companies should be allowed to account for things in their own way.

${ }^{50}$ See Shaxson, 2013, which explains how financial institutions use annualised IRR calculations which massively overstate returns.

${ }^{51}$ Richard (this special issue) further argues that "as a result of accounting measures being modified at certain points in history, capitalists recognize profits at an increasingly rapid pace following their initial investment, which, in turn, increases their eagerness to capture the fruits of those investments as soon as possible"

${ }^{52}$ Although this was with the proviso that companies "could only report unrealized gains in income for financial instruments where previous write-downs occurred." (Cascini and DelFavero, 2011, p 1).
} 
abolished and some withdrew funding from the FASB (Economist, $1998^{53}$ ). The arguments of the key players in the standard setting process were interesting and complex. For example, in the 1990s standard setters (IASB and FASB) wanted to distinguish between speculative hedges and risk removing ones (eg foreign exchange hedges linked to overseas sales ${ }^{54}$ from naked CDSs) (Bruce, 1994). But, it was argued that accounting standard setters could not write standards with sufficient detail to preclude financial engineering designed to hide more than it reveals ${ }^{55}$; nor could they write standards which can "judge" the intentions of companies in terms of whether they are taking risk avoidance measures or speculating (Scott Taub, the deputy chief accountant at the Securities and Exchange Commission).

Although the expansion of derivatives could be seen as a catalyst for the expansion of fair value accounting, under pressure from business, the accounting profession has also allowed valuations of traded assets to be based on financial models. This is another neo-liberal paradox. While the theoretical adherence to "market perfection" and information usefulness remains in place, the practice of accounting is, when it suits the parties involved, rather different. Consequently, in the case of "illiquid" assets, financial institutions can choose the assumptions which go into their asset and liability valuation models in order to maximise bonuses. The extreme case of this is the level 3 inputs of FAS 157, issued in 2006, in which assets and liabilities are measured according to models like the capital asset pricing model (CAPM). As suggested to earlier - there are serious problems with these models (see Toms, 2006). For example, the CAPM has problems both in terms of its basic assumptions and consequently in the possibility of empirically testing it. Theoretically according to the CAPM, the "market portfolio" includes all the assets which investors' hold (including land, slaves, paintings and so on). It also posits the existence of a "risk-free" investment possibility. In practice, the CAPM uses stock indices as a substitute for the market portfolio. Roll (1977) demonstrated that this substitution is problematic since the inability to view the true market portfolio could mean that the CAPM may not be empirically testable. Furthermore, the CAPM is based upon the belief that the market is perfectly efficient. In other words, each investor is given the same information and understands that information in the same way and can act upon that information. This renders the CAPM empirically untestable since such test would suffer from the Duhem jointness of testing problem (Hines, 1988b). Mark to model accounting could perhaps be more realistically described as "mark-to-myth" accounting. This form of valuation has proved to be attractive in the financial community since it can smooth the volatility that mark-to-market accounting may have produced in times of volatile markets.

Overall the new accounting standards relating to derivatives and fair value are extremely complex and contain hundreds of different rules, some of which conflict with each other (Butler, 2009). The FASB and IASB's standards do not converge (Baluch et al, 2011). In any case, once standards are set, companies can interpret accounting standards in various different ways to suit their own ends. In practice an auditor might arrive at a financial institution to be confronted by an extremely complex instrument (that they may not understand) and be asked to sign off on the way in which the institution had decided to account for it. Smith-Lacroix et al's (2012) study of the auditing of fair values in Canada concluded that ( $\mathrm{p} 50$ ) "It is probably no exaggeration to argue that to a significant extent, financial statements predicated on standards of fair value can be understood as being constructed through negotiations surrounding guesstimates - though being produced through

\footnotetext{
${ }^{53}$ http://find.galegroup.com/econ/infomark.do?\&source=gale\&prodld=ECON\&userGroupName=ustrath\&tabID=T003\&docPage=article\&d ocld=GP4100289930\&type=multipage\&contentSet=LTO\&version=1.0, accessed $1^{\text {st }}$ Dec 2011; THE ECONOMIST January 17, 1998 BUSINESS AMERICA V THE WORLD: ACCOUNTING STANDARDS IN DISPUTE

${ }^{54}$ Of course it might be difficult for an individual firm in the UK to find a firm in the US with exactly the same contract date and amount of money and so financial institutions have a role to play in enabling hedging of foreign exchange risk. Their commission could be seen as their "share" of the surplus value realised by the firms who wish to hedge their exchange risk. There might be a power battle over the size of commissions. Bankers who make money without producing anything may be described as parasites; nonetheless, in the specific case outlined here, their profits are ultimately derived from real production.

${ }^{55}$ Wittgenstein would argue that rules cannot be divorced from their context.
} 
apparently legitimate and powerful valuation techniques." Kahneman (2011) suggests that people are very reluctant to admit that they have trouble in evaluating their own judgments and that declarations of high confidence (of the type required by under pressure auditors) frequently tell you that individuals have constructed a coherent story in their minds; not one that is necessarily "true". Within the framework of accounting, there is always "room for manoeuvre" by experts.

In practice the major accounting firms in the US and Europe were directly involved in the process of securitisation and structured finance. Arnold (2009, p 804) states that, in "their capacity as advisors to investment banking clients, the major firms performed due diligence work, offered accounting and tax advice on off-balance sheet vehicles and assisted with the securitisation of trillions of dollars of mortgage backed securities (MBS) and collateralized debt obligations (CDOs)."

It is not argued here that, in the choice between historical cost accounting, fair value accounting or even mark-to-model accounting, that one is superior to another, but that financial institutions can embrace (for example) fair values when it suits them, and make arguments against them when it does not. Although, mark-to-model accounting is more open to manipulation, there is significant negotiation between the auditor and auditee in all fair value accounting numbers (Smith-Lacroix et al, 2012). The needs of individual capitalists frequently come into conflict with those of other capitalists. This means that it sometimes suits different companies to have different valuation techniques. Laux and Leuz, (2009), note that in the second half of 2008 when the crisis intensified, some banks raised concerns about the use of FVA, arguing that the use of market values was creating a downward spiral. However, other banks, for example, Credit Suisse (2008) and JP Morgan (2008) argued against a suspension of FVA and defended it even during the crisis. Laux and Leuz (2009) suggest that the arguments could be self-serving, essentially passing the blame for the crisis to accounting standards. The creation of accounting standards for derivatives is a highly contested terrain. Fair-value accounting and accounting for derivatives ${ }^{56}$ can take many different forms depending on the strengths of the various fractional interests to influence the final accounting standard.

Since the crisis new accounting standards have been issued, some of which have closed certain of the gaps, for example IAS 39 (Financial Instruments Recognition and Measurement) attempted to close the loophole which allowed derivatives to be kept off-balance sheet and it bases the classification and accounting of financial instruments as assets or liabilities on management intent. For example, if management say that they are holding an asset as available-for-sale (AFS) then it must be shown on the balance sheet at market value and any change in the market value must go through the profit and loss account. Whereas if management say that an asset is to be held-tomaturity (HTM) it would be held on the balance sheet at amortized cost regardless of its current market price. The exception to this is if a credit event occurs in which case the asset must be written down with the difference going through the profit and loss account. IAS 39 became relevant in the recent Greek debt crisis. Under IAS 39 accounting rules any sale of a bond at less than its book value, will crystallise a derecognition loss based on the sales proceeds. Any derecognition impacts both bonds held as available-for-sale (AFS) and held-to-maturity (HTM). However, there is still a way for banks to avoid derecognition losses. The IFRS system is principle-based, so it is potentially possible to "persuade" auditors to accept accounting results based on a "substance over form" argument. In the case of a bond exchange such as that contemplated in the Institute of International Finance Offer in the Greek banking sector, the argument would be that the exchange was economically equivalent to agreeing to extend the term of an existing bond and the fact that this had been achieved by substituting a new (longer) bond for the original shorter one was irrelevant from an accounting perspective.

\footnotetext{
${ }^{56}$ For example there are significant differences between IAS 39 (Financial Instruments Recognition and Measurement) and FAS 133 (Accounting for Derivative Instruments and Hedging Activities)
} 
This section briefly argued that fair value accounting is not a new concept and that accounting standard setters took several years to come up with a standard for derivatives. They had to confront the difficulties of understanding very complex instruments while also wanting to distinguish risk reducing derivatives from speculative ones. At the same time they were under the usual financial pressure from their paymasters. In terms of their role in the crisis both accounting regulations and accounting firms were complicit in the creation of a shadow banking system enabled massive amounts of off-balance sheet accounting and legitimated and realised speculative gains and losses. The rules on the recognition and measurement of financial instruments deliberately handed accounting "choices" to companies allowing them to "persuade" auditors and accountants to produce and sign off "partial" accounting statements. These practices gesture towards the solution to the paradox that the accounting regulatory system is expanding during a period in which the dominant rationality is anti-regulation. In practice, while companies may complain about how expensive regulation is, they have much freedom in the way in which their accounts are produced (very much akin to Watts and Zimmerman's accounting preferences outlined earlier) ${ }^{57}$. While it is certainly the case that neo-liberal accounting regulations can take many different forms depending upon the outcomes of complex unpredictable battles; importantly for this paper, the battles, and stakes are all based upon identical economic rationalities. These rationalities enable those involved in the battles to understand their interests in identical ways - maximization of their individual wealth and fulfilment of individual contracts. The next section briefly considers accounting from a Marxist perspective, drawing particularly on Marx's understanding of fictitious capital.

\section{A Marxist perspective on accounting for derivatives and fair value accounting}

As noted earlier, fair value accounting came under considerable criticism for its role in the financial crisis. From a Marxist perspective the question of whether derivatives should be measured at fair value or historic cost would not make sense. If a bank designs a purely speculative instrument, for example a naked credit default swap, the point is not whether or not it appears in the accounts at market value or cost, but that the instrument, and any profits which derive from it, are wholly fictitious and will never be paid out of the value creation process. From a Marxist perspective, no value has been created. A Marxist insight into the issue of derivatives is that any derivative whose value is purely speculative and not underpinned by the value creation process demeans money as a store of value. If these types of financial instruments are permitted to flourish and a speculative bubble to develop, then a crisis will unfold. In essence a Marxist understanding of accounting for derivatives, financial instruments or other forms of fictitious capital turns on whether these "investments" are used to create real value and whether their profits or interest are paid as a share of that value. So, for example, a Marxist analysis would argue that the interest on a bond which is paid out of surplus value is qualitatively different, from the profit on the sale of a credit default swap. Money cannot create money on its own.

A "Marxist accounting solution" to the problem of how to account for risk reducing instruments (forward foreign exchange contracts, credit default swaps and so on), would be to simply record the expenses connected with risk reduction derivatives as expenses. From a Marxist perspective, this would make sense since it would highlight the proportion of surplus value which is taken by financiers ${ }^{58}$. It would be possible for all derivatives to be accounted for in this way. This would require a fundamental move away from the accounting rules which, for example, would classify a derivative contract which demands payment in more than a year's time as a long term liability or pays future rewards, as an asset. However, it does not get round the problem of how to account for any contractual future cash flows. One practical (but not Marxist) solution to this would be to

\footnotetext{
${ }^{57}$ The function of accounting in society is incredibly complex. It legitimates (people rarely question numbers), provides a veil for companies to hide behind and makes neo-liberal ideas "performative.

${ }^{58}$ This accounting treatment would relieve some of the "artificial volatility" problems (see Butler, 2009).
} 
put any monies due in the future as (non-discounted) liabilities while not recognising future cash inflows until they arrive.

While the growth in derivatives may have been the catalyst for the expansion of fair value accounting, it is important to understand that fair value and fictitious capital are not direct equivalents. Indeed it is entirely possible to place the value of a fictitious capital instrument in the accounts at historical cost. In whichever way it is accounted for, any form of fictitious capital remains speculative. This means that the question of how investments should be accounted for is not a question of "intent". For example suppose Emeli, an ethical investment organisation, purchases a bond from a company whose sole purpose is to invest in "real capital" - for example, the machinery required to construct sustainable housing. Emeli disapproves of financialisation and intends to hold the bond until maturity. Under IAS 39, the bond would be classified as HTM and accounted for as an asset at cost price in Emeli's balance sheet. But, with all the best intentions in the world, the sustainable housing enterprise might fail. This is an inherent property of fictitious capital. And if Emeli is unaware the failure of the housing enterprise, then the losses on the bond will be hidden behind the ("safe") historical cost value of the investment on the balance sheet.

In this section it has been argued that accounting standard setting is increasingly international and funded by large private institutions. These institutions represent weighty factional interests which will fight hard for the creation of standards which will best suit them. Companies which do not like particular accounting standards can pursue many strategies. Not least, they can threaten to withdraw funding from standard setting bodies, move to more friendly bodies and put pressure on governments to overrule standard setters (as in the case of IAS 139). The accounting standards adopted since the crisis have been fragmentary interested interventions. Accounting technologies have enabled, legitimised, hidden and animated the activities of financial institutions. The technologies of accounting which decide when and how contracts (bonds, CDOs and so on) should appear (or not) in accounts and the profits/losses which derive from them is crucial to legitimating, and enabling the reproduction of fictitious capital. Accounting technologies make "the fictitious" "real". They have direct negative economic implications for the many, while enriching the few. In the short term financial instruments can be used to "create" accounting profits so that the senior staff of financial institutions can earn huge bonuses ${ }^{59}$ and shareholders large dividends or speculative profits. In the medium term investments which are not underpinned by any value creation will create financial havoc. Yet those who managed to accumulate their massive bonuses, golden parachutes and pension funds will be unscathed by the fallout. In 2007 when banks started to report losses, city traders in London took bonuses of $f 8.8$ bn (Butler, 2009). These traders will be the last to suffer from the current UK government austerity programme.

\section{Conclusion}

Although Marxist theory provides some interesting ideas about how to improve accounting standards, it is not the role of Marxist theory to solve the problems of capitalism, but rather to enable a deeper understanding of it. The recent crisis was not solely a financial/speculative crisis caused by too much investment in derivatives. Its roots were, in part at least, grown in the inability of people to pay their mortgages and to be able to command sufficient incomes to pay for the necessities of life (McNally, 2009). The trajectory of neo-liberalism and financialisation, has led to the impoverishment of the lives of many people, devastated the life chances of a generation of young people and potentially left the baby-boomer generation with the prospect of a miserable old-

\footnotetext{
${ }^{59}$ In effect risky "investments" are made which are legitimated and frequently hidden or disguised through the interpretation of accounting standards.
} 
age. Marxist theory can be used to warn of the insanity continuing to speculate/gamble rather than to invest in real capital ${ }^{60}$ but it cannot overcome the contradictions of capitalism.

One may well ask what lessons were learned from the crisis by those in power. In terms of academia, Gendron and Smith-Lacroix (this special issue) argue that very little has changed, especially among finance researchers. In the realm of practice, Farrell and Quiggin (2012) chart how governments, central bankers and economists changed in the four years after Lehman's collapse from being "Keynesians in the fox hole" to "merchants of austerity". In autumn 2008, the establishment was in crisis. This presented a brief window of opportunity for Keynesians to garner international support for their economic-stimulus packages and reform of the financial sector. As soon as the global economy appeared to have stabilised both governments and central bankers ${ }^{61}$ began to adopt austerity measures. Arguably, neo-liberalism's trajectory was slightly and temporarily diverted for a short period. For the majority of those at the top of the finance sector nothing much has changed. The value of global hedge-fund assets rose by a record $\$ 122 \mathrm{bn}$ in the first quarter of 2013 to $\$ 2.4$ trn. The private equity industry is larger. It had total global assets under management of more than $\$ 3.2 \operatorname{trn}$ in 2012 - the twelfth year of continuous growth since 2000 (Shaxson, 2013). Tellingly, Marx, wrote that,

"Advantageously positioned as they are, the bankers and other "gentlemen of high finance" can set about exploiting the financial system "as if it was their own private capital" and thereby can appropriate "a good deal of the real accumulation" at the expense of industrial capital." Marx, 1967, p 478

In 2014 a significant amount of money is still flowing into the finance industry at the expense of investment in the real economy. Hedge-funds and private equity firms siphon off massive commissions which might otherwise be used for more productive purposes.

Accounting is an integral part of the symbolic universe of neo-liberalism. Accountants and their technologies played a role in the crisis on many different levels. It has been argued here that a financial economic view of the world meant that both accountants (who did not give going concern qualifications to banks which failed) and accounting academics were incapable of warning of the impending crisis. Perhaps more importantly, their technologies animate and inform individual shortterm wealth maximizing strategies which have serve to enrich the few (at an alarmingly increasing rate) at the expense of the majority. In the wake of the growth in extreme forms of derivatives, standard setters became mired in debates about how to account for derivatives and there has been much debate about fair value accounting. In reality, in their drive for individualised wealth maximisation, different industries and institutions within the same industry, will battle to have the form of accounting standard that best suits their interests. And those fighting hardest for their factional interests are the paymasters of the profession. In terms of the contemporary debates in accounting surrounding whether or not we should have fair value accounting, mark to model accounting or something else which will give investors information about the future, the blunt fact is that such discussions totally miss the point that the value of claims to future cash flows are in Marxist terms fictitious ${ }^{62}$. In an entirely strategic manoeuvre, the IASB and FASB embarked on another Conceptual Framework project after the crisis. The outcome of this project to date has been that accounting practice has been refocused towards the needs of speculators in capital markets, away from the broader social and environmental concerns that may reflect the interests of

\footnotetext{
${ }^{60}$ Ultimately, nothing can solve the contradictions of capitalism and as Harvey (2011, p 274/5) argues “... a minimum of $3 \%$ compound growth forever, which is both empirically and conventionally accepted as necessary to the satisfactory functioning of capitalism, is becoming less and less sustainable".

${ }^{61}$ led by Jean-Claude Trichet in the Eurozone

${ }^{62}$ Interestingly, in 1938, former President Franklin Delano Roosevelt abolished mark to market accounting as it was believed that this valuation technique contributed to the severity of the Depression, thus causing financial institutions to fail (Cascini and DelFavero, 2011).
} 
the community at large. One of the eight parts of the project, the Framework 2010, embeds financialised markets at the centre of accounting practice (Zhang and Andrews, 2014). As in the field of financial capital, nothing much has changed in the field of accounting.

The one certainty in this discussion is that there will be another crisis. An important question is -how this will impact on the poorest in society and what can they do to protect themselves. One of the "rationalities" of the system is that somehow "risk can be traded away". The way to accomplish this is to acquire a customised derivative to hedge risk. How might this financial economic/zombie reality "touch" the poorest on the planet? Without any form of support or state safety-net we are compulsorily becoming "entrepreneurs of our own lives". For the majority, their largest form of wealth is their own ability to work and to earn wages. So currently individuals bear a risk (of falling income or unemployment) which cannot be traded because people are not commodities. If a person were a commodity, she could securitise herself. An individual could sell the exposure to the variability of her income for a guaranteed income stream. Of course, the individual would be indentured to the owner of the security (effectively becoming a slave) ${ }^{63}$. While this may seem farfetched, immoral and unthinkable, let us for one minute ask whether accountants would become involved in accounting for indentured people. Given accountants' historical record (for example in the holocaust, see Funnell, 1998), I for one, can imagine that some (zombie) accountants would rise to the intellectual challenge of accounting for securitised people so long as they can profit handsomely from their endeavours.

\footnotetext{
${ }^{63}$ This example is drawn from "The duality of labour and the financial crisis", Economic and Labour Relations Review, July 2010, p 49.
} 
Bibliography

Armstrong P., (1985). Changing management control strategies: The role of competition between accountancy and other organisational professions, Accounting, Organizations and Society, 10(2), $129-148$

Armstrong, P. (1987). The rise of accounting controls in British capitalist enterprises. Accounting, Organizations and Society, 12(5), 415-436.

Arnold, P.J., (1988). The limits of postmodernism in accounting history: The Decatur experience, Accounting, Organizations and Society, 23(7), 665-684

Arnold, P. J., (2009). Global financial crisis: The challenge to accounting research, Accounting, Organizations and Society, 34, 803-809

Arnold, P., and Cooper C., (1999). A Tale of Two Classes: The Privatisation of Medway Ports, Critical Perspectives on Accounting, 10, 127- 152

Arnold, P. J., and Sikka P., (2001). Globalization and the state-profession relationship: the case the Bank of Credit and Commerce International, Accounting, Organizations and Society, 26(6), 475-499

Baluch, C., Cohen, R., Soto, H., Tucker, P., Volkan, A., and Wright, G., (2011). Fair Value Accounting: Current Status and a Proposal for Convergence, The International Business \& Economics Research Journal, 10(4), 17-29.

Bay, C., (2011). Framing financial responsibility: An analysis of the limitations of accounting, Critical Perspectives on Accounting, 22(6), 593-607

Beaver, W. H., (1989). Financial Reporting, an Accounting Revolution, $2^{\text {nd }}$ edition, New Jersey: Prentice Hall

Beder, S. (1998). Global Spin: the Corporate Assault on Environmentalism, Chelsea Green Publishing Company, Vermont.

Bengtsson, E., (2011). Repoliticization of accounting standard setting - The IASB, the EU and the global financial crisis, Critical Perspectives on Accounting, 22, $567-580$

Berger, P. L., and Luckmann, T., (1966). The Social Construction of Reality: a Treatise in the Sociology of Knowledge, City Garden New York: Doubleday

Blackburn, R, (2006). Age Shock, London: Verso

Bourdieu, P., \& Wacquant, L. (1992). Invitation to Reflexive Sociology. Cambridge: Polity Press.

Bruce, R., (1994). The Times, Learning to play new instruments, July 28

Bryer, R. A., (1994). Why Marx's Labour Theory is Superior to the Marginalist Theory of Value: The Case from Modern Financial Reporting, Critical Perspectives on Accounting, 5(4), 313-340

Bryer, R. A., (1999a). Marx and Accounting, Critical Perspectives on Accounting, 10(5), 683-709

Bryer, R. A., (1999b). A Marxist critique of the FASB's Conceptual Framework, Critical Perspectives on Accounting, 10(5), 551-589 
Bryer, R. A., (2000a). The history of accounting and the transition to capitalism in England. Part one: theory Accounting, Organizations and Society, 25(2), 131-162

Bryer, R. A., (2000b). The history of accounting and the transition to capitalism in England. Part two: evidence, Accounting, Organizations and Society, 25(4-5), 327-381

Bryer, R. A., (2005). A Marxist accounting history of the British industrial revolution: a review of evidence and suggestions for research, Accounting, Organizations and Society, Accounting, Organizations and Society, 30(1), 25-65

Bryer, R. A., (2006a). Capitalist accountability and the British Industrial Revolution: The Carron Company, 1759-circa. 1850, Accounting, Organizations and Society, 31(8), 687-734

Bryer, R. A., (2006b). Accounting and control of the labour process, Critical Perspectives on Accounting, 17(5), 551-598

Butler, C., (2009). Accounting for Financial Instruments, West Sussex: Wiley

Cascini, K. T., DelFavero, A., (2011). An Evaluation Of The Implementation Of Fair Value Accounting: Impact On Financial Reporting, Journal of Business \& Economics Research, 9(1), 1-16

Casson, P., and Napier, C., (1997). "Representing the future: financial benefits and obligations, risk and accounting". In the Proceedings of the AOS conference on Accounting, Time and Space, 4-6 September, Copenhagen Denmark, Vol 1 pp 299 - 337

Chabrak, N., (2012). "Money talks: the language of the Rochester School", Accounting, Auditing \& Accountability Journal, 25: 3, 452 - 485.

Chabrak, N., (2014). The Shareholder value mythology and the market "communion", Law and Financial Markets Review, Feb, 1 - 12

Chiapello, E., (2007). Accounting and the birth of the notion of capitalism, Critical Perspectives on Accounting, 18(3), 263-296

Christenson, C., (1983). "The Methodology of Positive Accounting" Accounting Review, Jan, 1 -22

Clegg, S., Carter, C., Kornberger, M., ad Schweitzer, J., (2011). Strategy Theory and Practice, London: Sage

Cooper, C., Coulson, A., Taylor, P., (2011). Accounting for human rights: Doxic health and safety practices - The accounting lesson from ICL, Critical Perspectives on Accounting, 22(8), 738-758

Cooper, C., and Taylor, P., (2000). From Taylorism to Ms Taylor: the transformation of the accounting craft, Accounting, Organizations and Society, 2000; 25(6), 555-578

Cooper, C. and Taylor, P., (2005). Independently verified reductionism: Prison Privatisation in Scotland, Human Relations, 58(4), $467-522$;

Cooper, D. J., and Sherer, M. J., (1984). The value of corporate accounting reports: Arguments for a political economy of accounting, Accounting, Organizations and Society, 9(3-4), 207-232 
Davenport, T., (2004). Accounting Reform Can Only Do So Much, The American Banker, July 30

Davis, J. (2003). The Theory of the Individual in Economics: Identity and Value, London: Routledge

Deutsche Börse AG, (2008). The Global Derivatives Market: An Introduction, Apr

Dumenil, G, and Dominique L., (2004). Capital Resurgent: Roots of the Neoliberal Revolution.

Cambridge and London: Harvard University Press

Elliott, L., and Atkinson, D., (1998). The Age of Insecurity, Verso: London

Farrell, H., and Quiggin, J., (2012). Consensus, Dissensus and Economic Ideas: The Rise and Fall of Keynesianism During the Economic Crisis, March 9, available at

http://www.henryfarrell.net/Keynes.pdf (accessed 11 June 2013)

Fine, B., Lapavitsas, C., and Milonakis, D., (1999). "Addressing the World Economy: Two Steps Back", Capital and Class, 67, 47-90

Fine, B. (2007a) "Financialisation, Poverty, and Marxist Political Economy", Poverty and Capital Conference, 2-4 July 2007, University of Manchester.

Fine, B. (2007b) "The Historical Logic of Economics Imperialism and Meeting the Challenges of Contemporary Orthodoxy: Or Twelve Hypotheses on Economics, and What is to Be Done", European Association of Evolutionary Political Economy Conference, 1-3 November 2007, Porto, Portugal.

Fine, B., (2008a), Zombieconomics: The Living Death of the Dismal Science in the Age of NeoLiberalism, ESRC Neo-liberalism Seminar, 1st April 2008, http://www.cppr.ac.uk/centres/cppr/esrcneo-liberalismseminar/

Fine, B., (2008b), Looking at the Crisis through Marx: Or Is It the Other Way about?, working paper

Fine, B., (2009). "Neo-liberalism as Financialisation", in Saad Filho, Alfredo and Yalman, Galip L., (eds) Economic Transitions to Neo-liberalism in Middle-Income Countries: Policy Dilemmas, Economic Crises, Forms of Resistance. London: Routledge

Foucault, M., (2000). Ethics: subjectivity and truth, London: Penguin books

Friedman, M., (1953). Essays in positive economics, Chicago: University of Chicago Press

Funnel, W., (1998). Accounting in the service of the holocaust, Critical Perspectives on Accounting, 9(4), 435-464

Gendron, Y., Smith-Lacroix. J-H, (this special issue), The global financial crisis: Essay on the possibility of substantive change in the discipline of finance, Critical Perspectives on Accounting,

Guerrera, F., and Bullock, N., (2008). "Struggle to unearth quake's epicentre," Financial Times, October 31, http://www.ft.com/cms/s/0/f2701bcc-a6bb-11dd-95be000077b07658.htm|\#axzz1ej3P07fG 
Gup, B. E., and Lutton, T., (2009). Potential Effects of Fair Value Accounting on US Bank Regulatory Capital, Journal of Applied Finance, 19, $38-48$

Harney, S., (2010). Accounting, risk, and revolution, Critical Perspectives on Accounting, 21(1), 14-17

Harvey, D., (2006). Limits to Capital, $2^{\text {nd }}$ edition, London: Verso

Harvey, D., (2010). A Companion to Marx's Capital, London: Verso

Harvey, D., (2011). The Enigma of Capitalism, Exmouth: Profile

Hatherly, D., (2013). The Failure and the Future of Accounting, Surrey: Gower

Hayek, F. A., (1943). The Road to Serfdom, London:Routledge

Hayek, F. A. (1945). The Use of Knowledge in Society, American Economic Review, 35(4), 519-530

Hayek, F. A. (1948). Individualism and Economic Order, Chicago:Chicago Press

Hines, R., (1988a) Financial Accounting: In Communicating Reality, We Construct Reality Accounting, Organisations and Society, 13, 251-262

Hines, R. D., (1988b). A Popper's methodology of falsification and accounting research, Accounting Review, Oct, $657-662$

Hines, R., (1989). Financial Accounting Knowledge, Conceptual Framework Projects and the Social Construction of the Accounting Profession, Accounting, Auditing \& Accountability Journal. 2(2), 72 91

Hopwood, A. G., (2009). The economic crisis and accounting: Implications for the research community, Accounting, Organisations and Society, 34, 797- 802

Jensen, M, C., and Meckling, W. H., (1976). Theory of the Firm: Managerial Behavior, Agency Costs and Ownership Structure, Journal of Financial Economics, October, 3:4, 305-360.

Kahneman, D., (2011). Thinking, Fast and Slow, Allen Lane

Keynes, J. M., (1936). The General Theory of Employment, Interest and Money, Palgrave Macmillan

Kotz, M., and McDonough, T., (2010). Global Neoliberalism and the Contemporary Social Structure of Accumulation. In McDonough, T. Reich, M. and Kotz D. M., (eds), Understanding Contemporary Capitalism: Social Structure of Accumulation Theory for the Twenty First Century. Cambridge: Cambridge University Press

Krumwiede, T., (2008). The role of fair-value accounting in the credit-market crisis, International journal of Disclosure and Governance, 5(4), $313-331$

Kunkel, B., (2011). How Much Is Too Much? London Review of Books, 33(3), 9-14

Laux, C., and Leuz, C., (2009). The crisis of fair-value accounting: Making sense of the recent debate, Accounting, Organizations and Society, 34(6/7), 826. 
Lazonick, W. and Mazzucato, M. and Tulum, O., (2013). Apple's Changing Business Model: What Should the World's Richest Company Do with All Those Profits? (July). Accounting Forum,

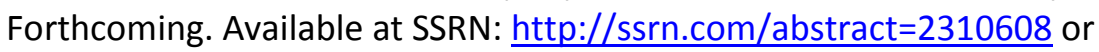
http://dx.doi.org/10.2139/ssrn.2310608

Lucas, R. (1987). Models of Business Cycles, Oxford: Blackwell

Magnan, M. and Markarian, G., (2011), Accounting, Governance, and the Crisis: Is Risk the Missing Link? Available at SSRN: http://ssrn.com/abstract=1879869 or http://dx.doi.org/10.2139/ssrn.1879869

Marsden, R., (1998). A Political Technology of the Body: How Labour is Organized Into a Productive Force, Critical Perspectives on Accounting, 9(1), 99-136

Martin, R., (1998). Fragmentation and Fetishism: The Postmodern in Marx, Critical Perspectives on Accounting, 9(1), 77-93

Martin, R., (2002). Financialization of Daily Life (Labor in Crisis), Philadelphia: Temple University Press

Marx, K. (nd). Capital: A Critique of Political Economy, Volume III, The Process of Capitalist Production as a Whole, Edited by Friedrich Engels, International Publishers, NY, On-Line Version: Marx.org 1996, Marxists.org 1999; https://www.marxists.org/archive/marx/works/download/pdf/Capital-Volume-IIl.pdf

Marx, K., (1967). Capital, International Publishers: New York

Marx, K., (1973). Grundrisse. Middlesex, England: Penguin Books

MacKenzie, D., (2006). An Engine, Not a Camera: How Financial Models Shape Markets, Cambridge: MIT Press

McNally, D., (2009). From Financial Crisis to World-Slump: Accumulation, Financialisation, and the Global Slowdown, Historical Materialism, 17, 35-83

Moseley, F. (2011) The whole and the parts: The early development of Marx's theory of the distribution of surplus-value in the grundrisse Science and Society, Volume 75, Issue 1, Pages 59-74

Nölke, A., and Perry, J., (2007) "The Power of Transnational Private Governance: Financialization and the IASB," Business and Politics, 2007; I(9)3: Article 4.

O’Neil, P., (2008). Clever Country Dumps Low-risk Compassion, Newcastle Herald, May 19 Available on-line: http://www.riskmanagers.com.au/risk-managers-articles/2008/5/19/clever-country-dumpslowrisk-compassion/

Power, M., (2010). Fair value accounting, financial economics and the transformation of reliability, Accounting and Business Research, International Accounting Policy Forum, 40(3), 197-210

Quiggin, J., (2012). Zombie Economics: How Dead Ideas Still Walk among Us, Princeton University Press: New Jersey 
Ramirez, C., (2001). Constructing the governable small practitioner: The changing nature of professional bodies and the management of professional accountants' identities in the UK, Accounting, Organizations and Society, 26(4-5), 391-418

Ravenscroft, S., Williams, P.F. (2009), "Making imaginary worlds real: the case of expensing employee stock options", Accounting, Organizations and Society, 34:6/7, 770-86.

Richard, J., (2005), The concept of fair value in French and German accounting regulations from 1673 to 1914 and its consequences for the interpretation of the stages of development of capitalist accounting, Critical Perspectives on Accounting, 2005;16, 825-850.

Richard, J., (this issue) The dangerous dynamics of modern capitalism (From static to IFRS' futuristic accounting), Critical Perspectives on Accounting,,

Robson, K., (1999). Social Analyses of Accounting Institutions: Economic Value, Accounting Representation and the Conceptual Framework, Critical Perspectives on Accounting, 10(5), 615-629

Roll, R., (1977). A critique of the asset pricing theory's tests Part I: On past and potential testability of the theory, Journal of Financial Economics, 4 (2), 129-176

Rossman, P. and G. Greenfield (2006) "Financialization: New Routes to Profit, New Challenges for Trade Unions", Labour Education, Quarterly Review of the ILO Bureau for Workers' Activities, no 142,

Saravanamuthu, K., Tinker, T, (2003). Politics of managing: the dialectic of control, Accounting, Organizations and Society, 2003; 28(1), 37-64

Sandage, S., (2005). Born Losers: A History of Failure in America. Cambridge, MA: Harvard University Press

Shaxson, N., (2013). The zombies of Mayfair, New Statesman, 28 June, 31 - 35

Sikka, P., (2009). Financial crisis and the silence of the auditors, Accounting Organizations and Society, 34:6-7, 868-873

Sikka, P., (2011). Accounting for human rights: The challenge of globalization and foreign investment agreements, Critical Perspectives on Accounting, 22(8), 811-827

Smith-Lacroix J-H, Durocher S, Gendron Y, (2012). The erosion of jurisdiction: Auditing in a market value Critical Perspectives on Accounting, 23:1, Pages 36-53

Spence, C., Carter, D., (2011). Accounting for the General Intellect: Immaterial labour and the social factory, Critical Perspectives on Accounting, 22(3), 304-315.

Stiglitz, J., (2002). Globalisation and its discontents, New York: Norton

Stiglitz, J., (2010). The Non-Existent Hand, London Review of Books, Vol. 32 No. 8 - 22 April, pages 17-18 (http://www.Irb.co.uk/v32/n08/joseph-stiglitz/the-non-existent-hand)

Stockhammer, E., (2004). Financialisation and the Slowdown of Accumulation, Cambridge Journal of Economics, 28(5), 719-41. 
Stout, L., (2012). The Shareholder Value Myth: How Putting Shareholders First Harms Investors, Corporations, and the Public, Berrett-Koehler: San Fransisco

Tett, G., (2009). Fool's Gold: How Unrestrained Greed Corrupted a Dream, Shattered Global Markets and Unleashed a Catastrophe, London: Abacus

Toms, S., (2005). Financial control, managerial control and accountability: evidence from the British Cotton Industry, 1700-2000, Accounting, Organizations and Society, 30 (7-8), 627-653

Toms, S., (2006). Asset pricing models, the labour theory of value and their implications for accounting, Critical Perspectives on Accounting, 17(7), 947-965

Toms, S., (2010), The labour theory of value, risk and the rate of profit, Critical Perspectives on Accounting, 21(1), 96-103

Toms, S., Beck, M., Asenova, D., (2011). Accounting, regulation and profitability: The case of PFI hospital refinancing, Critical Perspectives on Accounting, 22(7), 668-681

Wahlen, J. M., Boatsman, J. R., Herz, R. H. Jonas, G. J., Palepu, K. G., (2000). American Accounting Association's Financial Accounting Standards Committee: Response to the FASB preliminary views: Reporting financial instruments and certain related assets and liabilities at fair value Accounting Horizons, 14(4), 501-508

Walker, S. P. (2004). The genesis of professional organisation in English accountancy, Accounting, Organizations and Society, 29(2), 127-156.

Watts, R. L. (1977). Corporate Financial Statements, A Product of the Market and Political Processes," Australian Journal of Management, April, 53-75.

Watts, R.L., and Zimmerman, J. L., (1978). Towards a positive theory of the determination of accounting standards. The Accounting Review. (January), 112-134.

Watts, R. L. and Zimmerman, J. L., (1979). The Demand for and Supply of Accounting Theories: The Market for Excuses, The Accounting Review, 54(2), 273-305

Watts, R., \& Zimmerman, J., (1986). Positive accounting theory. New Jersey: Prentice Hall

Whittle, A., Carter, C., Mueller, F., 'Above the fray': Interests, discourse and legitimacy in the audit field, Critical Perspectives on Accounting, Available online 5 October 2013

Wilby, P., (2009). All of us live by the logic of finance, New Statesman, Feb, p 28 -

Williams, P.F. (2004), "Recovering accounting as a worthy endeavour", Critical Perspectives on Accounting, Vol. 15 pp.513-7.

Williams, R., (2008). Face it: Marx was partly right about capitalism, Spectator, 24 September

Zhang, Y., and Andrew, J., (2014). Financialisation and the Conceptual Framework, Critical Perspectives on Accounting, 25:1, pp. 17-26 